\title{
Revisiting international human rights treaties: comparing Asian and Western efforts to improve human rights
}

\author{
Dissa Syakina Ahdanisa ${ }^{1}$ (D) Steven B. Rothman ${ }^{1}$
}

Received: 3 May 2020 / Accepted: 11 October 2020 / Published online: 23 November 2020

(c) Springer Nature Switzerland AG 2020

\begin{abstract}
This paper presents a review of existing literature to understand the effects and effectiveness of human rights treaties in the Asia Pacific region, particularly in Southeast Asian countries, in contrast to Western nations. The review argues that factors at the international/treaty level and factors at the domestic state level increase the difficulty of implementing effective international treaties on human rights. At the international level, the treaties and organizations to which states belong suffer some weakness as discussed in international relations theories, while seven factors are particularly important for promoting effectiveness of international human rights treaties at the domestic level: political capacity, economic development, national human rights institutes, regional human rights courts, regional intergovernmental organizations, strength of civil society, and political stability. Although the number of international human rights agreements signed and ratified by Asia Pacific states is increasing following the trends of Western states, less research focuses on the implementation and effects of these institutions. Asia Pacific nations face vastly different conditions than Western nations, such as more complicated security environments, larger cultural and religious differences, and less development and democratic values in some cases. Due to these differences, it is important to consider other potential variables that influence efficacy of treaty instruments for non-Western nations. What are the differences between implementation of human rights treaties in Western and Asian nations? How do they affect the efficacy of international agreements on individual human rights?
\end{abstract}

Keywords Human rights · ASEAN $\cdot$ Western states $\cdot$ Treaties $\cdot$ International relations

Dissa Syakina Ahdanisa

syakdi18@apu.ac.jp

1 Ritsumeikan Asia Pacific University, Beppu, Japan 


\section{Introduction}

Western and Asian countries are known to differ on their perception of human rights. Generally speaking, Western nations assume that there are some universal and inalienable natural rights. This assumption about the nature of human rights, in some cases, predates the Universal Declaration of Human Rights and international human rights treaties (Freeman 1995). On the other hand, though some Asian countries assume the universality of some human rights, the leaders of these countries take a position that the implementation of the rights must consider the significance of national and regional particularities and various historical, cultural and religious backgrounds (a point of view often known as the "Asian Values") (Davies 2014a). In other words, while some human rights may be universal, the implementation of those rights differs due to local contexts (Chan 1995). In addition, Asian nations often emphasize the importance of community over the individual, and some Asian leaders perceive human rights to criticize existing domestic political relationship and government' authoritative power (Ghai 1995; Munro 2011).

Although both Western nations and Asian nations face difficulties implementing human rights treaties, Asian nations continuously seem to lag behind their Western counterparts, and in some cases have worsening records of human rights abuse. Despite the increase in the number and depth of international agreements, human rights violations continue to occur throughout different Asian nations. What accounts for the differences observed between Western and Asian nations regarding the implementation and effectiveness of human rights treaties?

In order to understand this puzzling difference between Asian nations and the West, this paper examines existing literature and research and presents seven factors that affect human rights effectiveness and implementation: political capacity, economic development, national human rights institutes, regional human rights courts, regional intergovernmental organizations, strength of civil society, and political stability. The analysis is completed through a process of qualitative comparative analysis between two groups of states with similar characteristics, Western states, and Southeast Asian states. These groups are chosen primarily on variation on the dependent variable regarding to the record of human rights observance. Although each group also has some variation between states, we believe there is more in common among the states than differences, which makes this comparison viable. The paper proceeds by first examining the concept of human rights and argues why human rights are important. Second, the paper analyzes the current conditions of human rights within the Western nations and in the Southeast Asian nations to put the research in context of the cultural and societal conditions and compare these conditions. Third, the paper presents factors related to the treaties that impact effectiveness derived from regime theory contrasted against realist understanding of treaty effects. Subsequently, the paper examines the state-level variables that influence human rights effectiveness. Finally, the paper concludes by providing directions for future research on human rights, particularly regarding the Asia Pacific and Southeast Asian region. 


\section{The concept of human rights}

In order to start our discussion about human rights, this section presents a brief concept about human rights that have been contested by various scholars. This section also argues that human rights interpretation evolves over time, while their protection and realization are not only beneficial to individuals, but also to states and the system.

When asked about the idea and foundation of human rights, many scholars have different perspectives. Based on current literature of human rights, Dembour (2010) classified them into four schools of thought, which are natural scholars, deliberative scholars, protest scholars, and discourse scholars.

Natural scholars argue that human rights are entitlements to specific objects that each and every person should respect (Gewirth 1996; Perry 1998; Donnelly 2013). Human rights are bestowed upon us by nature, referring to either God, Universe or reason, because we are human (Donnelly 2013). Natural scholars also claimed that our entitlement to human rights is because all human beings are the same (Gewirth 1996; Goodale 2009). In fact, Goodale (2009) added that the equality of every single individual is what causes the need for a special normative framework that is human rights. This idea of naturally given rights represents the orthodox view of human rights (Tasioulas 2015). Furthermore, natural scholars argued that human rights are enjoyed individually and through substantive law. In effect, they consider the emerging human rights law as an undeniable progress (Dembour 2010). All in all, natural scholars believe in human rights and are optimistic that society fully respecting human rights is realizable or may have already existed (Donnelly 2013; Perry 1998).

On the other hand, deliberative scholars suggest that human rights are political values selected by liberal societies to be espoused (Habermas 2015; Merry 2006; Campbell 2011). Human rights are exclusively appropriate to govern the polity, and are not relevant to the whole moral and social human life (Ignatieff 2003). In contrast to natural scholars, deliberative scholars asserted that human rights are not naturally given by God but based on the people's agreement on how to run the society (Habermas 2015). These scholars significantly uphold human rights law, as the law represents the true essence of human rights (Campbell 2011; Merry 2006). For deliberative scholars, human rights can be found in constitutional principles and serve as 'guidance,' realizable through political institutions and good procedural laws (Merry 2006; Ignatieff 2003).

Meanwhile, the third school of thought, the protest scholars, affirmed that human rights are claims and aspirations made by or on behalf of the oppressed and marginalized people (Stammers 2009). Human rights are something the people continuously fought for as they are the avenue to challenge the status quo (Stammers 2009; Baxi 2007). Protest scholars believe that human rights originated from historical development and the tradition of social struggles ingrained in the society, in which they argue, are more permanent than merely based on legal consensus (Derrida 2005; Baxi 2007). However, according to these scholars, human rights law consists of routines that only favor the elites, showing 
empty promises and at worst, a sham (Derrida 2005; Stammers 2009). The ideal utopia of human rights will never be realized, as it is always in the making and it needs to be continuously fought for (Nash 2001). Therefore, on contrary with two previous schools of thought, protest scholars argue that human rights law betrays the true idea of human rights, which results to rampant and never-ending human rights abuses in the world (Derrida 2005; Stammers 2009; Dembour 2010).

The last school of thought is the nihilists of human rights, the discourse scholars. They believe that human rights only exist because people talk about them (MacIntyre 2007). Human rights are fundamentally flawed and human rights law is similar to any other type of law in the world with no particular significance (Mutua 2002; Dembour 2010). These scholars deny that human rights serve as guides to solve problem in the world, but they acknowledge the power of language of rights to express political claims (Brown 2004). Some discourse scholars believe that human rights are a work of progress (Mutua 2002). However, others claim that human rights have always failed and never deliver on their promise to ensure equality of the people in the world (Brown 2004; MacIntyre 2007).

Nevertheless, other scholars affirm that what sets human rights apart from other types of rights are their modesty. Human rights contain specific rights addressing specific issues, but they are not expansive (Clapham 2015; Edmundson 2012). They are not too numerous nor demanding (Cohen 2004; Ignatieff 1999). Shue (1996) asserts that human rights address the "lower limits on tolerable human conduct" rather than "great aspirations and exalted ideals." With their modesty, human rights are able to accommodate for cultural variation among countries and allow more detailed decision-making in a state level (Rawls 1999).

Furthermore, human rights are also known to be contextual and their interpretation develops over time. Declarations or treaties of international and regional organizations such as the United Nations (UN) Charter and European Convention of Human Rights (ECHR) are acknowledged as living breathing instrument, which means that they evolve as time goes by and will be interpreted according to presentday situation (Moeckli and White 2018; Letsas 2013). Following the footsteps of ECHR, the Inter-American Commission of Human Rights also regards the American Convention of Human Rights as living instrument, representing the modern-day standard of morality, justice, and decency (Inter-American Commission on Human Rights 2000).

Meanwhile, specific human rights written on treaties such as International Covenant on Civil and Political Rights (ICCPR), International Convention on the Elimination of All Forms of Racial Discrimination (ICERD), and Convention on the Elimination of All Forms of Discrimination Against Women (CEDAW) are also interpreted according to present-day standard (Moeckli and White 2018). In Judge v. Canada, the UN Human Rights Committee had to decide whether Canada has breached the right to life under Article 6 in ICCPR by deporting the plaintiff to the United States where he had been sentenced to death penalty. The Committee has noticed factual and legal developments, including the changes in international consensus, in which more people in the world have now favored the eradication of death penalty (Moeckli and White 2018). The Committee agreed that Canada decision 
should have reflected the present-day situation and thus they ruled that Canada has violated Article 6 of ICCPR (United Nations 2003).

In addition to court's ruling, evolving interpretation of human rights can also be found in treaties' general comments. Convention on the Rights of the Child (CRC) emphasizes the right to be protected from corporal punishment in its general comments although the right was not discussed during the drafting process. However, corporal punishment has been more prevalent in the seventeen years since CRC was adopted, making the issue important to address (United Nations Convention on the Rights of the Child 2007).

Furthermore, scholars often argue about the universality of human rights. Natural scholars strongly agree that human rights are universal and their universality is proven by overlapping consensus in the world's view of moral equality (Dembour 2010). Accordingly, Donnelly (2013) asserts that all states consider international human rights to be a part of international law, shown by high ratification rate of human rights treaty. Moreover, all cultures, religions, and leading world views have some similar perspectives about values specified by international human rights (Donnelly 2013; Ishay 2008). Thus, according to natural scholars, human rights are universal because they are endorsed by leading world principles.

Meanwhile, deliberative scholars argue that human rights may or may not be universal since societies are very diverse. Thus, the universality of human rights can only be achieved through global adoption of liberal values they express (Campbell 2011). On the other hand, protest scholars only believe that universality of human rights exists because suffering, the source of human rights according to them, is universal (Dembour 2010). As for discourse scholars, they do not believe in the universality of human rights and equate it as Western way of modern imperialism (Dembour 2010).

Nevertheless, according to Mende (2019) human rights can be universal, but not colonialist universalism that rejects their particularities or context of origin, nor empirical universalism based on the assumption of overlapping consensus. Instead, it is the contextual universalism where human rights take their own conditions into account, assuming the heterogeneity of societies while being opened to be translated, transferred, extended, or challenged (Mende 2019). Mende argued that this kind of universalism embraces dynamic pluralism and will lead to more emancipatory international human rights discourse.

In accordance to Mende's argument, it is very important to acknowledge the heterogeneity of states and regions in the world. Vienna Declaration emphasizes that national particularities must always be taken into consideration (The World Conference on Human Rights 1993). Moreover, by considering local culture in interpreting human rights, we will be able to pave ways for the most vulnerable people to participate in self-emancipation (Freeman 2013). Furthermore, if we found cultural resistance in promoting human rights values, Nussbaum asserts that we must take it seriously (Nussbaum and Sen 1993). It will enable us to investigate on how to make the victim of human rights abuse who are often exploited in the name of culture, thinking of alternative condition when their human rights are not violated (Nussbaum and Sen 1993). Also, by looking into 
the cultural resistance of human rights, we might able to see that the actual problem may be the need of political or economic reform (Freeman 2013).

Lastly, the protection and realization of human rights will not only benefit individuals but also the state and the global system. For individuals, human rights highlight the personhood and the obligation of being human (Beitz 2001). They enhance our effectiveness and make our lives more meaningful as we are obliged to do no harm (Griffin 2008). Human rights also serve as an avenue for human beings to be empowered and stand up for themselves (Donnelly 2013).

Furthermore, in the state level, human rights serve to improve the lives of citizens of the country. Donnelly (2013) argues that human rights are the most effective solution to overcome the threats of modern markets, as they become the tools to fact-check the most powerful institutions to be compatible in providing the life of dignity for the people. Protecting human rights also enhances political stability and encourages a more open and economically efficient society, making it more attractive for foreign direct investment (FDI) (Blanton and Blanton 2007). Moreover, human rights improve state's development by incorporating good governance and establishing a non-discriminatory environment that encourage participation and empowerment of the people, values that are indispensable to development (Hamm 2001). Additionally, states that have ratified international human rights treaty may also benefit from improved transnational network, increased foreign aid, trade, or other transnational relationships (Hathaway 2007).

Meanwhile, in the system level, protection of human rights may lead to more effective model of institutions and social system. Pogge argued that in order to realize human rights, we need to design institutions and social system that can secure people's access to the substance of those rights (Pogge 2002, 2005; Jaggar 2010). Enabling those systems will benefit the global poor and create a more just society (Pogge 2005).

With all those benefits gained by improving human rights, this paper argues that it is important for Southeast Asian countries to protect their citizens' human rights. By doing so, the region, notoriously known as being unfriendly towards human rights, may improve its reputation and credibility (Davies 2014a; Ciorciari 2012). As Blanton and Blanton (2007) and Hathaway (2002, 2007) have expressed earlier, countries that respect human rights are also exposed to certain economic benefit from their commitment. Hence, improving human rights may improve the regional stability and economic cooperation of Southeast Asian countries, the forefront of both motives and declared aims of the region's intergovernmental organization, ASEAN.

In conclusion, people have debated the idea, concept, and foundation of human rights from different perspectives. Human rights are contextual and their interpretation changes over time. Although their universality is contested, scholars agree that we need to consider national particularities and take cultural resistance seriously when endorsing the value of human rights. Protecting human rights benefits individual, state, and the global system, thus it is important for Southeast Asian region, which was infamous to be unreceptive towards human rights, to gain trust and credibility by improving its human rights track record. It may sound challenging, but it is not impossible. 
Therefore, in the following section, the paper examines the condition of human rights in both Southeast Asian and Western countries. Both regions have past records of violating human rights, with present-day challenges to overcome. Subsequently, this paper also presents several state-level variables to improve human rights through a more effective treaty implementation.

\section{Regional conditions for human rights}

In order to understand the issues around human rights within these two regions, this section presents the background of human rights conditions and treaty compliance within Southeast Asia (concentrating on ASEAN nations) and the West. Although it is clear that states within ASEAN and within the West vary with each group over human rights abuses and compliance, it is a useful starting point for comparison. Since much of the observed empirical differences between Western and non-Western states regarding compliance with human rights norms are attributed to cultural factors, this division on cultural bases is central to the discussion. Before discussing the two regions in detail, this section firstly addresses the debate of whether human rights are Western by acknowledging the pluralist origin of human rights and highlighting human rights violations committed by Western countries.

The discussion of human rights within the Western states and Eastern states of the world has been ongoing for a while. Despite the argument that human rights are 'Western' and are just created to validify states' own human rights violations (AnNa'im 1999; Karan 2004; Mayer 2017; Sen 1999; Tatsuo 1999; Zakaria and Lee 1994), scholars have emphasized that the international discourse of human rights did not originate from merely one homogenous value system or culture, but from various heterogenous sources (Bhambra 2007; Brotton 2002; Cousin 2011). NonWestern religion and culture such as Hinduism or the Islamic concept of "Ijtihad" gave foundations to the values of moral agency and tolerance, which are very often found in the current-day international human rights discourse (Mende 2019).

Scholars also agreed that Western countries have not always been the front proponents of human rights (Freeman 2013; Talbott 2005). Wars, colonialism, and slavery in the West showed that historically Western countries have also violated human rights. For example, many Europeans considered the indigenous populations of their colonies as 'savages' or 'barbarians,' legitimizing the enslavement of Africans, the killing and conquest of native Americans and similar abuses of other native people (Ishay 2008). Meanwhile back in the 16th and 17th century, Christianity was considered as the most intolerant religion (Zagorin 2003). The expulsion of Jews and Muslims from Spain following the Alhambra Decree in 1492 and the Thirty Years War between Protestant and Catholic that gave birth to the Treaty of Westphalia were some of the historical events showing the religious intolerance in the West (Haas 2013; Brackney 2013). In fact, scholars have asserted that the first proponents of religious tolerance were not from the West, but leaders from the East such as Ashoka the Emperor of India (Sen 1999) and Cyrus the Great-King of Persia (Talbott 2005).

Even in the present day, we still see countries in the West violating human rights. Australia, for example, is known to have referred asylum seekers with derogatory 
terms such as 'boat people' (Devetak 2004) and has used deterrence in its policy to prevent refugees from entering its border (Pickering and Lambert 2002). Australia also forcibly transferred people who sought asylum to Nauru, a remote Pacific island nation, denying them of proper medical care and detaining them in inhumane condition for extended period (Amnesty International 2016).

In addition to that, the recent report from Amnesty International identified human rights violations committed by the police during the Black Lives Matter protest in the United States. During the protest in May 2020, the police used excessive force and chemical irritants towards the protesters while also targeting journalists and street medics (Amnesty International 2020).

Meanwhile in 2018, Human Rights Watch reported widespread hostility and intolerance such as Anti-Semitism, racism and Anti-Muslim violence persisted across the EU (Ward 2018). Recently, with the outbreak of corona virus, several political parties in Western states such as United States and United Kingdom have also latched onto the Covid-19 crisis to advance anti-immigrant or white supremacist that demonizes refugees and foreigners, particularly of the Asian descents (Human Rights Watch 2020a).

Furthermore, the Western countries are also no strangers to violating economic, social, and culture rights. Australia has failed to provide proper mental health support for prisoners with disability in its Western Australian prisons, many of whom are Aboriginal and Torres Strait Islanders prisoners (Human Rights Watch 2020b). The United Kingdom has initiated welfare structuring and cuts since 2010, resulted to reduction of welfare support and increased number of people going hungry at an alarming rate (Human Rights Watch 2019a). Currently, the situation has worsened by the COVID-19 pandemic, as government has failed to ensure all children in the UK, especially the children from low income families to have access to food as the country closed schools, neglecting the children's right to food and nutrition (Human Rights Watch 2020c).

After acknowledging that Western countries also violate human rights, we may shift our attention to the institutionalization of human rights that is often debated as being 'Westernized' thus making it bias towards the violation of human rights done by their members from Western countries. Panikkar (1982), for example, emphasized the liberal protestant root in Universal Declaration of Human Rights (UDHR) as a proof that the document was made by and only for Western culture. Meanwhile Douzinas (2007) acknowledged other non-Western states, mostly decolonized states, participated in institutionalization of human rights, however, they only do so to follow the powerful Western states.

Nevertheless, many other scholars argued otherwise. According to Waltz (2002), the institutionalization of human rights came out as a result of active collaboration between both Western and Non-Western countries, which in turn made it pluralist and global. The UN General Assembly in 1946 bore witness to the statement as non-Western countries such as Egypt, India, Cuba, and Haiti argued for resolution against issues such as racism, genocide, and apartheid system in South Africa (Lauren 2011). On contrary, Western countries such as Australia, United Kingdom, and 
the USA supported South Africa claiming state sovereignty and non-intervention rule after being criticized of its apartheid system (Lauren 2011).

The birth of UDHR was also the result of collaboration, as out of 48 countries voted in favor of the Declaration, 33 countries were non-Western (Mende 2019). The global effort of institutionalizing human rights that started in 1940s, continued to 1950 s and 1960s with active contributions from both Western and Non-Western countries. Establishment of binding treaties, declarations and international treaty bodies were also the results of diverse perspectives of colonized or newly decolonized non-Western states (Barreto 2013; Nkrumah 1962; Rajagopal 2006). Furthermore, the discussion conducted by delegations from non-Western states during the drafting process of ICCPR and ICESCR, development of human rights mechanism concerning racism and right to self-determination in 1960 as well as facilitation of the first foreign policy strategy integrating human rights by Jamaica in 1964 are some of the examples of how heterogenous the process of human rights institutionalization was (Reus-Smit 2001; Jensen 2016).

The global participation in international human rights framework continues to the present day. The discussion to draft the latest international human rights treaty, UN Convention of Rights for People with Disability (UNCRPD) was proposed by Mexico in 2001 (United Nations Department of Economic and Social Affairs (UNDESA) Disability, n.d.). The drafting process then involved disabled people organizations (DPOs) from different countries, while the current UN Committee in charge to monitor the treaty consists of disability rights experts from both Western and non-Western countries, creating a 'paradigm shift' in the international human rights discourse (Cogburn and Reuter 2017; Harpur 2012; Kayess and French 2008).

Although the international human rights framework is argued to be global and pluralist, the heterogeneity of both Western countries and the Southeast Asian countries has led to distinct approaches to human rights. In the following sections, the paper presents how those different approaches are significantly influenced by different administration of leaders in both Western countries and Southeast Asian Countries. Concurrently, it also argues that Southeast Asian nations in particular suffer from worse political and economic conditions than the Western counterexamples and exhibit different cultural and religious views of human rights norms and importance in society.

\section{Southeast Asia}

Southeast Asian countries are very diverse. Each of the countries has their own perspective towards human rights, the issue that has divided Southeast Asian countries the most (Ciorciari 2012). Discussion of human rights often divided the countries into three different groups. Tommy Koh, the Singaporean Ambassador-at-Large, argued that the three groups are 'supportive group,' consists of Indonesia, Malaysia, Philippines and Thailand; 'not enthusiastic group,' that consists of Cambodia, Laos, Myanmar and Vietnam; and the 'middle group' which consists of Singapore and Brunei (Koh 2009; Ciorciari 2012). 
Meanwhile, Davies divided Southeast Asian countries into three groups based on their track record of human rights (Davies 2014a). Indonesia and the Philippines are considered as 'progressive countries,' as they have embraced democracy ${ }^{1}$ and have put significant effort in adhering to human rights law. Singapore, Malaysia, and Thailand are the cautious ones, because these countries, while conforming to the law, still refuse global standards, especially in the area of civil and political rights. Lastly, Cambodia, Laos, Myanmar, Vietnam, and Brunei are considered recalcitrant, due to the slow progress of human rights compliance (Davies 2014a). These ten nations make up the Association of Southeast Asian Nations (ASEAN), emphasizing the principles of unanimity and equal participation, with preference towards consultation and consensus-based decision-making process (Acharya 1997; Narine 1997; Davies 2012). The association avoids public confrontation or interfering with other member states' internal affairs, including the affair of human rights.

Despite scholars' earlier groupings, human rights remained an issue distinctly approached by different administration of governments in some ASEAN countries. For example, the Philippines and Indonesia have seen some fluctuations in their human rights records under different leaders. Prior to the declaration of martial law in 1972, the Philippines have had constant democratic rule since 1935 and was regarded as the oldest democracy in the Southeast Asian region (Sidel 1995). However, its experience with authoritarianism during President Marcos from 1972 to 1986 brought the Philippines listed as a nation that violated human rights, particularly targeting political opponents, journalists, and activists (The New York Times 1977; Pernia 2019).

After the successful ousting of Marcos in 1986, the Philippines became the first country in Southeast Asia to create a National Human Rights Institution (NHRI) following the decree of the newly elected President Cory Aquino (Jetschke 1999). The country also ratified prominent international human rights treaties, created Constitutional Commission on Human Rights, an independent agency to deal with individual complaint of human rights, and established a new constitution emphasizing on human rights and outlawing torture (Jetschke 1999; Green 1989). These efforts have led to major improvements of human rights in the country (Amnesty International 1977, Jetschke 1999). Philippine's positive commitments towards human rights continued to the era of President Arroyo and President Benigno Aquino, whom have offered to assist ASEAN in creating ASEAN International Commission of Human Rights (AICHR) by hosting the secretariat in the country (Ciorciari 2012).

However, with the election of Rodrigo Duterte as president in 2016, scholars and international human rights organizations have argued that human rights conditions in the Philippines have worsened. Human Rights Watch (2017) reported that Duterte's war on drugs policy is responsible for the deaths of more than 12,000 Filipinos who

\footnotetext{
1 Davies (2014a) defined both Indonesia and the Philippines as countries that have incorporated democratic liberal norms domestically with political pluralism as the foundation of their political system. Vienna Declaration defined democracy as based on the free will of people to determine their own "political, economic, social and cultural system." (The World Conference on Human Rights 1993). For more references investigating the relationship between human rights and democracy check Griffin's "On Human Rights" (2008) and Beetham's "Democracy and Human Rights" (1999).
} 
are mostly urban dwellers living in poverty. Police officers were responsible in carried out many of these extrajudicial killings. The policy instilled fear, devastated the community spirit and weakened the already ineffective judicial system of the country (Espenido 2018). Accordingly, it has also eroded the rule of law as well as checks and balances in the country that resulted to dire implications for human rights (Kenny 2018). Meanwhile, the Philippines has also withdrawn from International Criminal Court in May 2019 (European Union 2019) and refused the UN effort to conduct an official visit and investigation (Morales 2018). Duterte has been regarded to bring Philippines into a "human rights calamity," its worst human rights crisis since the dictatorship of Ferdinand Marcos (Amnesty International 2018; Human Rights Watch 2018).

Similarly, Indonesia has also experienced its fair share of human rights fluctuation under different leadership of its presidents. During the administration of President Sukarno, sparked by the conflict with Indonesian Communist Party, Indonesian Army and civilian vigilantes killed approximately 500,000 people following the $30^{\text {th }}$ September coup de etat (Cribb 1990). In addition to the killing, people were tortured and placed in detention without trial (Amnesty International 1977; Kammen and McGregor 2012). Furthermore, under the regime of the following president Suharto, Indonesian military had committed human rights violations such as torture, massarrests, sexual violence, and long-term imprisonment in East Timor since its invasion in 1975 and during Indonesia' occupation in the region (Taylor 1999).

However, the fall of Suharto's leadership marked an important step in Indonesian history of long-awaited freedom and democracy (Druce 2019). Since then, Indonesian legal system has improved by including legal framework for protection of human rights across different sectors and subsequent ratification of international human rights treaties (Juwana 2006; Hadiprayitno 2010). The following administration of President Habibie supported the independence of East Timor after a referendum in 1999, while many cultural and social rights were recognized by the state during the administration of President Wahid (Juwana 2006; Eldridge 2002).

Indonesia's pluralism, fundamental freedoms, and vibrant civil society are the key features marking its progressive human rights track record over the last couple of years (European Union 2019). Indonesia also shows high commitment to improve its human rights in international level by being the member of the United Nation Security Council (2019-2020) and United Nation Human Rights Council (2020-2022). Under the current administration of Jokowi, Indonesia attempts to enhance the lives of West Papuan citizens, who were often deprioritized by previous administrations through economic development (Druce 2019). Recently, albeit its still-strong military presence which may or may not hinder the process (Aspinall 2010; Hadiz and Robinson 2013; Posner and Vermeule 2004), Jokowi's administration also tries to resolve Indonesia's past human rights violations by creating a non-judicial special agency ensuring a more peaceful and reconciliatory process (McGregor and Setiawan 2019).

Nevertheless, despite the fluctuations of each country's human rights record, in 2012, Southeast Asian nations created the first charter of human rights in the 
region, the ASEAN Human Rights Declaration (AHRD). ${ }^{2}$ The Declaration states the region's commitment to economic, cultural, and social rights, which have been the focus since ASEAN was established, as well as to civil and political rights (Davies 2014a). The unification of all different members' point of view in the Declaration shows the acknowledgement of the existence of human rights and the importance within the development agenda for the region.

However, critics of the declaration dubbed the document as a "disappointment," because civil society in the region was excluded from the drafting process (Human Rights Watch 2012; Clarke 2012; Renshaw 2013). The US administration claimed that the declaration did not adhere to global standards, and may be utilized as a "shield" to avoid Western criticism on perpetual human rights abuse in the region (Baer 2012). The declaration also showed a resurgence of Asian Values, highlighting the relativism of human rights implementation, in accordance to "different political, economic, legal, social, cultural, historical and religious backgrounds." (ASEAN 2012). Moreover, the declaration also has self-limiting causes and imposes no punitive sanction ${ }^{3}$ (Davies 2014a). The participation of recalcitrant states in this declaration was also seen merely as mimetic adoption, rather than a fully committed gesture, to maintain ASEAN reputation in international eyes (Katsumata 2009, 2011).

The progress on human right treaties implementation also seems slow in the region. Out of nine core UN International Human Rights Treaties, only three treaties are ratified by all ten Southeast Asian countries, the Convention on the Elimination of all Forms of Discrimination Against Women (CEDAW), Convention on the Rights of the Child (CRC) and Convention on Rights of Persons with Disabilities (CRPD). These treaties covered politically less-sensitive areas, which explained their quick ratification (Ciorciari 2012; Davies 2014b).

Nonetheless, even with ratifications, these ASEAN states continued to avoid obligations using reservations in the ratified treaties. On CEDAW and CRC, states utilized their reservation on the basis of the constitution, national laws, religion, or existing socio-political conditions in the country (Linton 2008). This suggests that private rights such as the right to marry or divorce, status of women, protection of children and religious issues, pose most serious challenges to the universality of human rights and implementing improvements of those rights for ASEAN nations (Cerna 1994).

Some scholars suggest that reservations are beneficial, allowing states to join despite some objects due to the intrusive nature of the treaties. Human rights treaties

\footnotetext{
${ }^{2}$ A declaration, unlike a convention, is not legally binding. Member states do not have a legal obligation to abide by the declaration. However, a declaration is sometimes the precursor to more binding treaty, for example: American Declaration of the Rights and Duties of Man preceded the American Convention on Human Rights (Renshaw, 2013). Thus, AHRD should be viewed as a first step toward a more binding human rights instrument of the region.

${ }^{3}$ Although it is also worth noting that core international treaties such as ICCPR, CAT and CEDAW do not have strict enforcement mechanisms (Hathaway 2007). Ratifying countries are required to submit reports to the treaty bodies, and incompliance to those treaties risked facing public shaming by international organizations, civil society, and NGOs (Lebovic and Voeten 2006; Hafner-Burton 2008; Hill 2010; Cole 2012).
} 
Table 1 Human rights index (CIRI 2014)

\begin{tabular}{lllllll}
\hline Region & $\begin{array}{l}\text { Empower- } \\
\text { ment rights }\end{array}$ & $\begin{array}{l}\text { Freedom } \\
\text { of religion }\end{array}$ & Worker's rights & $\begin{array}{l}\text { Women's } \\
\text { economic } \\
\text { rights }\end{array}$ & $\begin{array}{l}\text { Women's } \\
\text { political } \\
\text { rights }\end{array}$ & $\begin{array}{l}\text { Independence } \\
\text { of the judici- } \\
\text { ary }\end{array}$ \\
\hline $\begin{array}{l}\text { Average } \\
\text { Southeast } \\
\text { Asian }\end{array}$ & 4.6 & 0.5 & 0.3 & 1.1 & 1.8 & 0.6 \\
$\begin{array}{l}\text { Countries } \\
\text { Average } \\
\text { Western } \\
\text { Countries }\end{array}$ & 11.8 & 1.7 & 1.2 & & & \\
\hline
\end{tabular}

have become the most reserved treaties in the world (Linton 2008), and in some cases, the reservations can be helpful by encouraging state engagement, becoming a stage needed by these countries to transform disinterest to engagement and finally to compliance (Fournier 2010). However, in some cases, the reservations may show the reluctance to commit to human rights law implementation (Thio 1999).

In addition, many states do not comply with monitoring and reporting provisions with the treaties. While report submission to the treaty body can positively show the state's effort to respect human rights (Mechlem 2009; Wotipka and Tsutsui 2008), only Brunei, Myanmar, and Singapore are currently up to date on their reporting obligations in 2014 (Davies 2014b). Thus, late submissions of these reports prevent treaty body to do their job effectively (Davies 2014b).

To summarize, Southeast Asian nations can be divided into three categories based on their conformance to human rights regulations: progressive countries, cautious countries, and recalcitrant nations. ASEAN nations unanimously agreed to the ASEAN Human Rights Declaration, but the document lacks legal status and does not bind member states to the declaration, unlike a treaty. In addition, the general trend among these ASEAN nations is slow, at best, toward adhering to current global standards of rights and transparency/monitoring requirements.

\section{The West}

Western Europe, often dubbed to have the most advanced human rights system in the world, is considered a role model in human rights discourse, especially after the creation of European Convention for the Protection of Human Rights and Fundamental Freedom (ECHR) in 1953 (Mower 1976; Moravcsik 2000; Davies 2012; Donnelly 2013; Haas 2013). Governments are cooperative (Mower 1976) and intergovernmental organization, such as European Union (EU), strategically utilizes rewards and sanctions to encourage compliance among the member states (Davies 2012). This "conditionality politics" is what influences EU successful socialization of human rights and other norms (Davies 2012).

In addition to the European countries, other Western states such as United States, Canada, Australia, and New Zealand have also shown high respect towards human 
Table 2 Political terror scale 2019

\begin{tabular}{llll}
\hline Region & \multicolumn{2}{l}{ Political terror scale (2019) } & \\
\cline { 2 - 4 } & $\begin{array}{l}\text { Amnesty inter- } \\
\text { national }\end{array}$ & $\begin{array}{l}\text { Human rights } \\
\text { watch }\end{array}$ & State department \\
\hline $\begin{array}{l}\text { Average South- } \\
\text { east Asian } \\
\text { countries }\end{array}$ & 2.60 & 1.70 & 2.50 \\
$\begin{array}{c}\text { Average West- } \\
\text { ern countries }\end{array}$ & 1.29 & 0.14 & 1.29 \\
\hline
\end{tabular}

rights in comparison to Asian countries (Cingranelli et al. 2014). Comparison of the average scores of six human rights indices from 2014 CIRI datasets for nine Southeast Asian nations and 28 Western nations ${ }^{4}$ (North America, Europe, Australia, and New Zealand) shows substantial differences (Table 1).

Empowerment rights index represents government respect for seven human rights, which are freedom of foreign movement, freedom of domestic movement, freedom of assembly and association, freedom of speech, electoral self-determination, and freedom of religion and worker's rights. The score ranges from " 0 " that represents zero government respect towards the aforementioned rights to "14"representing full government respect. The Western states scored almost tripled the score of their Southeast Asian counterparts, indicating that the average Western states respect human rights more than the Southeast Asian countries.

This condition of higher respect toward human rights in Western states in comparison to Southeast Asian states is also supported from the most recent Political Terror Scale (PTS) that shows the degree of physical integrity rights violations by agents of the states, coded from reports of Amnesty International, US State Department and Human Rights Watch (Gibney et al. 2019) (Table 2).

The higher score indicates higher level of abuse, murder, and torture-showing more frequent physical integrity rights violations. Western nations consistently showed lower scores in all three sources of the scale, which signifies the region's strong human right regime.

The West also cares about promoting human rights values overseas. For example, through its policies and foreign aids, the United States has shown greater concern and created greater impact on developments related to human rights than any other nation (Barnds 1995; Donnelly 2013). Although scholars still argue the effectiveness of foreign aids towards the improvement of human rights (Cingranelli and Pasquarello 1985; Lebovic and Voeten 2009), by creating USAID in 1961, Human Rights and Democracy Fund in 1998 and established human rights acts such as the North Korean Act of 2004, the USA has shown its commitments to support other countries contingent to their human rights progress (Haas 2013). Scholars also

\footnotetext{
${ }_{4}$ Western nations include the following countries: United States, Canada, United Kingdom. Norway, Sweden Portugal, France, Spain, Italy, Germany, Belgium, Switzerland, Netherlands, Denmark, Ireland, Finland, Luxembourg, Estonia, Latvia, Lithuania, Poland, Czech Republic, Slovak Republic, Hungary, Croatia, Slovenia, Australia, and New Zealand.
} 
argued that human rights play a more prominent role in US decision to provide economic aid in comparison with the decision to provide military aid (Abrams and Lewis 1993; Apodaca and Stohl 1999; Carleton and Stohl 1987; Cingranelli and Pasquarello 1985; Meernik et al. 1998; Poe 1992).

Many countries in the West have helped transitioning nations or newly established democratic nations to implement effective human rights policies (Posner 2014). Some even withhold their trade deal or agreement. For example, the European Union temporarily terminated "Everything But Arms" (EBA) trade scheme for Cambodia, including its tariff preferences, due to Cambodia's failure in improving its human rights condition (European Union 2019). In addition, Western states frequently criticize other governments that permit human rights abuse, including Southeast Asian leaders' perception on universality of human rights (Cerna 1994).

However, human rights policies by the Western nations are not without any criticism. Scholars question the United States' enthusiasm to encourage other nations to abide by human rights treaties, while being reluctant in applying the treaties themselves, in particular regarding the usage of torture by the United States to interrogate terrorist suspects after the 9/11 tragedy (Foot 2005), and the unusual silence of American human rights groups regarding potential domestic human rights violations regarding racism and inequality (Ignatieff 2005).

Moreover, similar to Southeast Asian countries, changes in government administration have also affected the US general approach towards human rights. Although the USA has established various policies concerning human rights, especially as a part of their foreign affairs since the era of President Carter, the focus of those policies varied from one president to another (Cingranelli and Pasquarello 1985; Donnelly 2013; Wainwright 2018).

During President Carter's administration, the USA focused on human rights violations committed by allied states such as South Africa and Argentina (Wainwright 2018). Meanwhile, human rights were considered as deciding factors to deploy military aid during Reagan and Bush administration (Apodaca and Stohl 1999; Choi et al. 2020). Military intervention was aimed to end conflict such as in Somalia during the administration of President Bush Sr. and to Kosovo and Bosnia during President Clinton's administration (Wainwright 2018). Subsequently, the administration of President Bush Jr. and President Obama shifted the priority of US human rights policy to countries in Asia such as North Korea, Iran, and Myanmar (Wainwright 2018).

However, as President Trump promoted the idea of "America first," people have noticed the President's disinterest to prioritize human rights in the US foreign policy (Wainwright 2018). Under Trump Administration, the USA has withdrawn from several international institutions and human rights treaties such as UN Human Rights Council, UNESCO and Paris Agreement (Kamuf Ward and Catherine 2019). In turn, the administration has created its own human rights advisory body, the Commission of Unalienable Rights in 2019 to provide the US foreign policy with reformed ideas in the human rights discourse (US Department of State 2019). Nevertheless, many human rights groups are worried that the commission will instead undermine the universality of human rights and will impede the protection of many rights such as women's rights, rights of the LGBTQI community and the economic, 
social, and cultural rights in the USA (European Union 2019). Meanwhile, domestic policies of the administration such as drastic federal cuts for housing, healthcare and education have also reduced the protection against discrimination especially towards people of color (Kamuf Ward and Catherine 2019).

Furthermore, in Europe, the rise of radical right-wing populism and parties with extreme xenophobic movements and anti-establishments such as France's National Front, the far-right Alternative for Germany party, Syriza in Greece, UK Independence Party in the UK, and Podemos in Spain have challenged and demobilized liberal democracy (Caramani 2017; Galston 2018; Pernia 2019). They impacted EU policies most significantly in the areas of migration and climate legislation (Balnaves et al. 2020). As they framed their migration policy to 'save our European way of life,' they created a rhetoric of "us vs them" that dehumanizes migrants (Ward 2018; McDonnell and Werner 2020).

At the same time, there are also reports about fascists attacking refugees, NGO volunteers and journalists (Smith 2020).In addition to poor treatment of migrants at the refugee camps, EU's excessive obsession with border security has adversely affected development programs and exacerbated the number of dangerous and illegal attempts at migration, which are often resulted to lethal consequences (Fine et al. 2019).

The latest World Report of Human Rights Watch (2019b) also reported that there is still discrimination among ethnic minorities in developed European nations. Anti-Muslim and anti-Semitic attacks are still rampant, including the attack on the accommodation of asylum seekers in Germany. France also made the headline with abusive counterterrorism policy that undermines rights to liberty, as well as their alliance to countries with reputation as human rights violators (Human Rights Watch 2019b).

In summary, Western nations have a longer historical adherence to human rights norms and a much greater participation in international human rights policies, even to the point of pressuring other nations to improve their human rights conditions. Western nations often face criticism from others, however, because they sometimes lack full implementation of human rights and even violate human rights in a small number of cases. In some cases, criticisms are politically motivated, though this does not mean they lack substantive merit. As mentioned earlier, in comparison, ASEAN nations' recent creation of some human rights institutions and increasing engagement with a few international rights treaties does not move the nations far toward implementing human rights agreements and improving human rights conditions. The use of reservations and the lack of penetration of human rights into the private spheres are just two examples of ways these nations have resisted changes to their behavior. Thus, Western nations appear to be better placed for human rights implementation measures and protections, while ASEAN nations are in a better position to make the most improvement. It is important to recognize that human rights in the Western nations have been quite strong and gaining strength since the end of World War II, while ASEAN nations' progress has been lackluster. This presents a large opportunity for ASEAN nations to improve. 


\section{Conditions for human rights effectiveness}

Before examining the empirical factors that contribute to human rights effects and effectiveness, this section examines the theoretical issues involving treaty effects and effectiveness from an international relations perspective. International relation is often used to discuss important issues of human rights because of the importance of international policies on intervention (Alexander 2000), the importance of international law in relation to international human rights norm creation (Finnemore 1996a) and legal obligations for states (Goodman and Jinks 2004). Scholars divide international relations theory into three primary paradigms, such as realism, liberal institutionalism, and constructivism. Realism defines the international system through a series of assumptions on the necessity of self-help for states that drive their desire for increasing power to survive, their rational decision-making systems, and a tendency toward stability and balance of power (Waltz 1979). Institutional theories suggest that states have more interests than power and survival and are subject to constraints and influence through international and domestic institutions (Milner 1997; Leeds 1999; Iida 1993; Gourevitch 2002), though often share many assumptions of the international system with realist theory (Keohane 1984).

Realist theory suggests strongly that treaties only affect states when the interests of powerful states align with those treaties to enforce them (Mearsheimer 1994); however, liberal theorists and other scholars suggest the potential for treaty effects outside the power relations between states (Ruggie 1995). As a primary question, therefore, we must examine the extent to which treaties matter outside the power relations among states. If treaties do not affect states, then we must reduce the argument about human rights improvements to the power relations among states and relegate our study to realist theory. Scholars have conducted several studies on the effectiveness of human rights treaties, and we can divide the results into direct and indirect impacts on adherence to human rights principles. In general, scholars show that direct impacts of treaties on domestic human rights are limited, while there is greater potential for improvement of human rights from treaties through indirect mechanisms.

For direct effects, there are two primary considerations in the literature. First, the monitoring mechanisms of treaties are considered to be weak and the treaties mainly serve promotional or socializing function (Donnelly 1986, 2013; Forsythe 1985, 1991; Opsahl 1995; Ramcharan 1989). As a part of monitoring procedure, states submit reports to a relevant treaty body for a periodic review (Davies 2014b). In addition to self-report on a periodic basis to the treaty body, it is necessary for the states to involve in a 'constructive dialogue' about the treaty implementation and measures the states have taken with a relevant treaty body (Egan 2020). Unfortunately, many states are struggling to submit the reports on time (Donnelly 1986, 2013; Opsahl 1995). There are also reports found to be written by states own official, which created uncertainty on the content objectivity and credibility (Robertson 1981; Steiner and Alston 1996). Since there are very few, if any, consequences for states written into the agreements, state incompliance goes unpunished. 
Second, human rights treaties do not affect state behavior because some states join treaties without the good faith effort to improve human rights. States may join, instead, to deflect foreign criticism (Forsythe 1985), or due to pressure by more powerful nations (Donnelly 2013). Pressures to adhere to human right treaties lead countries to join human rights treaties, although they do not possess enough capacity to implement the treaty. This leads to non-compliance; thus, treaties are seen to do very little in ensuring better states' behavior, and in some cases worsen the human rights performance among ratifying states by deflecting attention from the human rights violations (Hathaway 2002).

However, treaties may indirectly improve human rights conditions through the longer-term process of internalizing new norms of appropriate behavior consistent with human rights. Human rights treaty affects domestic law which decides how quickly and effectively a state can make constitutional or legal reform. This reform then modifies political institutions to protect rights. In addition, ratifying a treaty is a step in a long socialization process within the international community that influences a state's willingness to protect human rights (Keith 1999). Treaties influence individual countries' perceptions of what constitutes acceptable behavior (Hathaway 2002). Countries gradually internalize values and norms expressed on those treaties, transforming their own practices.

Treaties and human rights law also have the capacity to start processes and dialogue that involves learning over time, leading up to eventual change in belief about rational or appropriate actions (Abbott and Snidal 2000). Goodman and Jinks (2003) also stated that ratification of human right treaties serves as a point in the broader process of incorporation of human rights norms into national law. Increasing communication among rights and beginning dialogue among nations may also contribute to internalization of norms and appropriate behavior over time. This interaction occurs repeatedly and can extend time horizons increasing the chances that actors will adhere to human rights mechanisms or engage in future cooperation around human rights (Axelrod 1997; Keohane 2015).

Human rights agreements also provide rules and structures to pressure the authority, creating a platform for determining what constitutes appropriate behavior (Chayes and Chayes 1993; Franck 1988; Lutz and Sikkink 2000). Many scholars are optimistic about the effects of human rights treaties in the longer term through the internalization of norms process. When states make commitments to international legal norms, their government generally acts accordingly in line with the treaties (Chayes and Chayes 1998; Finnemore 1996b; Goodman and Jinks 2003; Henkin 1979; Koh 1997; Mitchell 1993). Under this management view of compliance, even if joining the treaty forces states to change their behavior in costly ways, states are generally committed to the goals of the treaties they join (Hathaway 2003, 2005; Hafner-Burton and Tsutsui 2007). Hafner-Burton and Tsutsui (2007) also emphasizes that treaty ratification is not merely a symbolic act, but as an expression of preference for reform.

Nevertheless, scholars also emphasized that human rights treaties are most effective when countries have met certain conditions, such as strong democratic institutions and the presence of civil society. Countries with stronger democratic governing systems appear more likely to comply with their treaty obligations (Hathaway 
2002), which in turn creates better human rights performance. In addition, the strength of civil society and inclusion of veto players (Neumayer 2005; Lupu 2015) also improve the performance of human rights treaties in a country.

In summary, there are several variables that alter the effectiveness of international treaties on states: strength of monitoring mechanisms, state willpower to change human rights conditions, norm internalization, extending time horizons and repeated interaction, and the strength of substantive clauses in the treaties. Although previous research illustrate that there are few short-term direct impacts of human rights treaties on state human right performance, there are greater opportunities in longterm socialization and norm development. Therefore, despite realism's contention that treaties do not matter in international affairs, that potential effects occur through long-term processes. In addition to characteristics of the treaties, there are a number of characteristics at the state level that also contribute to the effectiveness of human rights treaties, which is discussed in the next section.

\section{Key factors of human rights implementation: Southeast Asia vs the West}

Based on the literature, seven intervening factors affect state behavior toward human rights in addition to the influence of international treaty institutions and norms: Political Capacity, Economic Power, National Human Rights Institutions (NHRIs), Regional Human Rights Courts/Commission, Regional Body or Intergovernmental Organization, Civil Society, and Political Stability. Some of these factors, such as political capacity, economic power, and political stability, are key concepts, shown to have affected respect towards personal integrity rights, as they reoccurred in several studies such as Poe and Tate (1994), Poe et al. (1999) and Hathaway (2002). In addition to that, some studies regarded factors such as NHRIs, and Regional Human Rights Courts/Commission as necessary instruments towards more effective human rights treaty implementation, due to their functions in international human rights system (Tan 2011; Cole and Ramirez 2013; Leach 2013; Muntarbhorn 2013). This project expands the scope of the analysis and uses these seven factors to investigate how they differ between Western and Southeast Asian states. While discussing each of these seven factors in more detail, the paper argued that NHRIs, Regional Human Rights Courts/Commission and Regional Body or Intergovernmental organization are the three most defining factors to ensure effective implementation of human rights treaty.

\section{Political capacity}

Political capacity involves "the degree of control that state agents exercise over persons, activities, and resources within their government's territorial jurisdiction" (McAdam et al. 2004, p. 78). Essentially, this involves the degree of development of domestic institutions that assist in the implementation of government policy. Political capacity is an important factor that affects the nation political system, which then 
affects government capabilities to implement policies (Hui 2005; Fukuyama 2013). States with high political capacity are better able to enact change inside the state, whether beneficial or not toward the population as a whole. If the state ratifies an international treaty protecting human rights, it is easier for states with higher political capacity to enact changes based on the treaty domestically.

To implement human right treaties effectively, scholars agree that political capacity is one of important aspects. States equipped by adequate capacity to avoid legislative and constitutional hurdles or constraint will be able to socialize the international human rights law into their domestic practices effectively (Posner 2014). Research shows that stronger democratic institutions and more veto players that make up political capacity improve the effect of human right treaties in a state (Davenport 1995; Poe and Tate 1994; Poe et al. 1999). Hathaway (2002) and Neumayer (2005) argue that countries with strong democratic government systems are more likely to comply with their treaty obligation, which in turn creates better human rights performance.

Legislative veto powers increase the difficulty of implementing policies and increase the requirements for consent over domestic institutions and important decision makers. By having the consent of actors and institutions serving as veto players, policies enacted are more likely to stick and continue (Lupu 2015), which leads to more sustainable implementation. Fewer veto powers allow changes to occur more readily making enacted policies less sticky within the democratic system.

In comparison to Southeast Asian nations, Western nations have more liberal democracies with more veto players that support human rights issues. Polity, for example, is a quantitative measured index of democracy where the higher scores represent more democratic states. Comparison of the average polity score for nine Southeast Asian nations and the aforesaid 28 Western nations (North America, Europe, Australia, and New Zealand) shows a dramatic difference: an average score of 1 for Southeast Asian nations and 9.5 for Western nations (Center for Systemic Peace 2019). In democratic nations, stronger democratic systems increase potential effectiveness of human rights treaties, however, in the context of ASEAN nations, state elites are primarily responsible for determining state policies even in democratic states (Emmerson 2005). These elites, whose subjectivity and biases ${ }^{5}$ may get in the way, also play a central role implementing human rights treaties, even in the more democratic parts of ASEAN. This creates a hurdle in achieving objective and optimal implementation. In other words, less democratic systems and fewer number of veto players makes implementation different from Western nations.

\footnotetext{
5 Also refer to Table 1: Independence of the Judiciary scores of Southeast Asian countries and the Western states. This variable indicates the extent to which the judiciary is independent of control from other sources, such as another branch of the government or the military. A score of 0 indicates "not independent," a score of 1 indicates "partially independent" and a score of 2 indicates "generally independent" (Cingranelli et al. 2014). The Southeast Asian states' average score of 0.6 is way lower than the Western states' average score of 1.9, indicating the lack of independence in their judiciary bodies.
} 


\section{Economic development}

Development generally coincides with higher human rights compliance and furtherance of human rights within domestic politics (Mitchell and Mccormick 1988; Poe and Tate 1994; Davenport 1995; Blanton 1999; Milner 2002; Richards et al. 2001). As states progress through the stages of development, they maintain larger financial capacity and infrastructures that are better able to implement human rights. Economic development is generally measured by the wealth of the nation such as the Gross Domestic Product (GDP) (Blanton and Blanton 2007).

Implementing human rights treaties is costly (Hathaway 2007; Posner 2014). Many times, states must create special task forces or training to carry all of the states' obligation in accordance to the treaties, which requires financial support (Chayes and Chayes 1993; Cole 2015). To socialize international human rights law into the domestic practices, countries also need to administer teams of lawyers, raising salary of its staff and in some cases, enforcing anti-corruption law, all in which are very expensive (Neumayer 2007; Posner 2014).

In terms of development, although there is some variation among all nations and within nations, again there is a clear distinction between Southeast Asia nations and the Western Nations. Using the same countries for polity, examining the average GDP for nations in the west and Southeast Asia shows a dramatic difference, approximately USD 1525 b for Western nations versus USD $328 \mathrm{~b}$ for Southeast Asian nations (The World Bank 2018).

In addition to development level, corruption also interferes with the economic capacity of nations to implement human rights. Many Southeast Asian nations are developing countries and are in the 50 ranking out of 180 countries, of Corruption Perceptions Index 2018 (Transparency International 2018). This index, with number " 1 " being the most corrupted country in the world, shows that corruption is a prevailing issue in the region. The elevated levels of corruption increase the costs of implementing human rights treaties due to the need to combat this corruption by increasing salaries or investigating and punishing illegal activity. On the other hand, corruption is rarely an issue for countries in the West, reducing the financial burden.

In addition to less corruption, increased economic power and financial capacity allow Western nations to incentivize other countries with foreign aids and other financial rewards, to adhere to human right treaties. In other words, Western nations have an excess of financial resources beyond what is necessary to implement their own policies, which allows them to act altruistically toward improving human rights elsewhere (Posner 2014).

\section{National human rights institutions (NHRIs)}

The United Nations describes national human rights institutions (NHRIs) as "state bodies with a constitutional and/or legislative mandate to protect and promote human rights" (OHCHR 2010, 4:20). This broad definition allows for a wide range of institutions to serve in this role, though generally this institution is responsible for 
three primary functions: receiving funds to protect human rights (OHCHR 2010), reporting on domestic human rights, and ensuring implementation of human rights treaties (Tan 2011). They are the bridge between national laws and policies of a nation with international human rights treaties.

Unlike non-governmental organizations (NGOs), NHRIs are not allowed to advocate for specific policy positions. NHRIs generally take form as a commission, ombudsman or a hybrid of the two, and have a wide range of duties, such as investigating human rights violations in both private and public sectors as well as assisting national human rights education programs (Tan 2011).

NHRIs play a significant role in ensuring human rights treaties are implemented effectively. They confirm that the government behaves in accord with what they have ratified on paper. Also, they facilitate the diffusion of international rights into domestic political settings (Cardenas 2003).

Some states also delegate their reporting duty to NHRIs, which encourage more transparent and independent reporting (Rejali 2009). NHRIs also mobilize domestic actors (Simmons 2009) and establish a relationship with civil society, as they act as a bridge between the government and civil society (Tan 2011).

Currently, out of 10 Southeast Asian countries, only 5 nations have NHRIs, which are Indonesia, Thailand, Philippines, Malaysia and Myanmar (Davies 2014b). All of them are registered under a prominent regionwide network of NHRI, the Asia Pacific Forum (APF) of NHRIs.

However, protecting human rights through NHRIs in Southeast Asia are not without challenges. In some cases, NHRIs are appointed by executive officials of the country, which made their independence often questioned (Muntarbhorn 2013). At the same time, non-pro human rights governments in Southeast Asia also often hamper the performance of NHRIs. For example, NHRIs in The Philippines, the Commission on Human Rights of the Republic of the Philippines (CHRP) have struggled in protecting human rights, especially regarding extrajudicial killings cases due to President Duterte's war on drugs policy since 2016. The president's rhetoric against human rights limits the support to CHRP. Authorities tampered with evidence and often refused to cooperate. Government has significantly cut the CHRP's budget and crippled CHRP's interaction with international human rights system. On top of that, the government withdrew the Philippines from the Rome Statute of the International Criminal Court, successfully cut off the vast network of cooperation of local and international organization to support the protection of human rights in the country (Netipatalachoochote et al. 2020).

Meanwhile in Thailand, the government utilizes legal means to impede the performance National Human Rights Commission of Thailand (NHRCT). The government withdrew protective mandates NHRCT used to hold and officials are unresponsive in answering NHRIs requests or recommendations (Netipatalachoochote et al. 2020). Thus, although NHRIs in Southeast Asia may have mandates to receive complaints or to give recommendation of remedial to concerned parties, government may employ legal and political action to get in the way of the implementation.

Additionally, NHRIs in Southeast Asia are not judicial institutions and have no power to litigate (Muntarbhorn 2013). Moreover, all the five NHRIs take the model of commissions, which is viewed as an advisory body instead of human rights 
ombudsmen that have investigatory power (Pegram 2010). Commissions are often favored by abusive governments to "to feign support for human rights" (Cole and Ramirez 2013).

Their initiation may also have served simply as an act for external audience. For example, in Indonesia, NHRI Komnas HAM was created in 1993 amidst growing international human rights abuses (Carver 2004; Jetschke 1999)_-1 week before the World Conference on Human Rights, suggesting that it is merely an act to improve Indonesia's image (Cole and Ramirez 2013).

Meanwhile, Europe has a coalition of 44 NHRIs under European Network of NHRI (ENNHRI). As the number of NHRIs is growing the region, some countries in Europe, such as Finland and Belgium, have more than one NHRIs (Carver 2011; European Network of National Human Rights Institutions (ENNHRI) n.d.). Many have the format of ombudsmen and are also accredited by the Global Alliance of NHRI (GANHRI).

Effective human rights treaty implementation in Europe relies on the strength and durability of the NHRIs, which are largely influenced by regional intergovernmental bodies such as European Union (EU) and Council of Europe (CoE). Scholars agreed that the conditionality of European Union membership has been an effective way to increase the establishment of NHRIs in Europe, especially in Central and Eastern Europe (Carver 2011; Pegram 2010). The EU also play an important role in strengthening the capacity of NHRIs in Europe, by including the assessment of member states' NHRI performance in country reports, as well as inserting NHRIs in instruments that require participating states to abide to certain standards of human rights performance such as The European Instrument for Democracy and Human Rights (Lacatus 2019).

Although the USA does not have NHRI, it reinforces human rights law through its independent judiciary ${ }^{6}$ at both federal and state government level (OSCE 2015). The US State Department stated that there are more than 140 state and local governments within the country that are equipped with human rights or civil rights agencies and commission ${ }^{7}$, all to ensure that the country adhere to human rights treaties it has ratified (OSCE 2015).

Unlike in Southeast Asia, NHRIs in the Western countries also support the regional judicial protection of human rights. In Europe, NHRIs work alongside European Court of Human Rights by making occasional interventions, following up Court's case law, as well as monitoring and advising the judgements executed by national authorities (Leach 2017). In the Inter-American human rights system,

\footnotetext{
${ }^{6}$ Howard and Carey (2004) argued that independent judiciary is substantively and statistically significant for the development of civil and political rights.

7 The United States has established US Commission on Civil Rights in 1975 that has played a major role in giving recommendations for the US government in protecting the civil and political rights of its citizens (The Human Rights Institute and the Leadership Conference on Civil and Human Rights 2012). It is also important to acknowledge that there was a debate of transforming the US Commission on Civil Rights into a more broadly mandated US National Human Rights Institution. Groves (2013) rejected the idea, condemned it as 'radical,' pointed out that the idea will potentially turn the platform into harassing US businesses and industry in the name of human rights.
} 
NHRIs have the power to lodge petitions with the Inter-American Commission on Human Rights (Reif 2004).

As the functions, operation, and composition of NHRIs are regulated by the Paris Principle (De Beco 2007), NHRIs status in accordance to the Paris Principle is officially examined by Global Alliance of NHRI (GANHRI), accrediting them into either 'A: Fully compliant'; 'B: Partially compliant' or 'C: Non-compliant' (Global Alliance of National Human Rights Institutions 2019). Using the same countries for polity and GDP, there are 22 NHRIs in the 28 Western countries with accreditation status 'A.' On the other hand, only 3 out of 5 NHRIs in Southeast Asia with accreditation status 'A.' These different results of GANHRI accreditation also affect the strength and durability of NHRIs, as NHRIs with GANHRI accreditation are more like to become more stronger overtime (Lacatus 2019).

One study conducted by Welch (2017) shows the significance of NHRIs in implementing human rights treaties. Using statistical data from 153 countries from 1981 to 2007, Welch pointed that the presence of NHRI in countries that ratified UN Convention Against Torture (CAT) has fundamentally decreased the chances of the states to violate human rights by practicing torture. The reason is because NHRIs act as information providers to domestic and international audiences about the legal obligation arising from human rights treaties and the state's compliance. In addition, Cole, and Ramirez (2013) pointed that the existence of NHRI also leads to better protection of physical integrity rights. Their analyses of 143 countries between 1981 and 2004 illustrates that NHRIs improved physical integrity rights outcomes, those are not associated with civil and political rights outcomes.

Southeast Asian countries are shown to have less respect towards human rights, especially the physical integrity rights, in comparison to the Western countries (Cingranelli et al. 2014). The latest Physical Integrity Rights Index showed that ASEAN countries scored on average 3.7, much lower than the Western countries that have an average score of 7.1 The index indicates government respect for physical integrity rights indicators concerning torture, extrajudicial killing, political imprisonment, and disappearance. It ranges from 0 (no government respect for these four rights) to 8 (full government respect for these four rights).

Moreover, the effectiveness of human rights treaties implementation in Southeast Asia is stalled by the limited number of national human rights institutions in each of member states (Clarke 2012). Thus, in correlation to Welch (2017) and Cole and Ramirez (2013), the limited number of NHRIs in Southeast Asia in comparison to the Western countries and the challenges they face above affected the respect towards human rights in general.

\section{Regional human rights courts/commission}

Regional human rights courts and commissions act as judiciary bodies within the context of particular regions and help implement regional human rights instruments. These courts assist implementation by receiving and processing human rights complaints from individuals and states, organizing public hearings, making determinations on human rights violations, and providing access to other courts that may 
order legally binding sanctions on violators (OHCHR n.d.). Judicial institutions help implement treaties by interpreting treaty text, determining violations, and assigning punishments to violators.

These institutions offer individuals greater access to the courts to report violations and offer their expertise within the regional context that global courts lack. Because regional courts are designed to be independent from states, they provide neutral objective assessments to help improve effectiveness of human rights instruments (Donnelly and Whelan 2017). Individuals need access to independent institutions rather than those within governments when governments are accused of violating individual human rights. Most importantly, these regional human rights mechanisms have advantages due to their greater historical and socio-cultural knowledge of the region, which give them credibility and shield to avoid sentiments of infiltrating the region with foreign standards.

Established in 2009, ASEAN Intergovernmental Commission on Human Rights (AICHR), is the regional human rights body in Southeast Asia, created to promote and protect human rights in the region. Scholars argued that the most notable achievement of the body is the creation of ASEAN Human Rights Declaration in 2012, as the declaration united ten Southeast Asian countries with diverse point of views on human rights matter (Davies 2014a; Ginbar 2010; Renshaw 2013). AICHR, however, maintains a vague Term of Reference (ToR). The body is founded to promote human rights, yet its ToR also states that AICHR respects the independence of each member state, and upholds non-intervention with internal affairs of other member states (Davies 2012). In one estimation, AICHR is a "thinly veiled instrument" designed to defend ASEAN position when there is any inquiry regarding human rights practices in the area (Munro 2011). The representatives of the body are appointed by each member state of ASEAN, with obligation to report to their own government; however, they can be withdrawn by their appointing government at any time. The ToR stated purpose also includes bearing national and regional particularities when promoting human rights (ASEAN Secretariat 2009). Additionally, the mandates reveal no provision for investigations, fact-finding, or country visits to follow up cases (ASEAN Secretariat 2009). Due to this, scholars are skeptical with the independence of AICHR to enforce human rights law successfully in Southeast Asia (Clarke 2012; Renshaw 2013; Munro 2011).

In addition to AICHR, Southeast Asian countries also have two sectoral bodies: The ASEAN Commission on the Promotion and Protection of the Rights of Women and Children (ACWC) and the ASEAN Committee on the Implementation of the ASEAN Declaration on the Promotion and Protection of the Rights of Migrant Workers (ACMW) included in regional human rights system. However, both sectoral bodies have more facilitative role rather than substantive role. Furthermore, unlike NHRIs in the region, ACWC, ACMW and AICHR, do not have procedure to receive complaints from individuals nor power to investigate them with a view to advocate legal redress (Muntarbhorn 2013).

In the West, the European Court of Human Rights enforces European Convention for the Protection of Human Rights and Fundamental Freedom (ECHR) since 1953, which has been ratified by all members of Council of Europe (Mower 1976). Early on, the ECHR faced opposition from recalcitrant states, however, after five 
decades all Western European states progressively adapted domestic law to include the ECHR. ECHR has earned the title of the most "advanced and effective" international regime to impose human rights in the world (Moravcsik 2000).

Moreover, the convention has two key optional provisions involving the jurisdiction of the Court of Human Rights and the right of individual petition to the commission. These allow greater connection to civil society by extending jurisdiction and allowing individuals to petition their cases to appear before the Court (Mower 1976). This connection with civil society and individuals regarding human right abuses is missing in AICHR, as AICHR does not have any formal mechanism of receiving complaints of human rights abuses (Muntarbhorn 2012). With this limitation, a regional human rights body will have lesser exposure to human rights condition in a grassroots level to check whether the treaty has been implemented effectively.

The European Court of Human Rights is the oldest regional human rights court in the world, yet with more states accession to ECHR, the Courts role has evolved over time. Not only that the Court continue to enhance standards of human rights protection of states where treaty compliance is strong, it also must settle human rights violation cases in newer member states of Council of Europe (Leach 2013). When interpreting ECHR, the Court consider ECHR as a living instrument, ${ }^{8}$ acknowledging the changes of societal attitudes and perception in their judgment (Letsas 2013, Moeckli and White 2018, European Court of Human Rights 2020).

The European Court of Human Rights ensures that all the decisions made are independent. All 47 judges in the Courts are elected by majority vote in the Parliamentary Assembly of Council of Europe, from among 3 candidates nominated by each state (European Court of Human Rights 2020). Their decisions are binding. Unlike AICHR, The European Court of Human Rights employs multifaceted approach including a thorough fact-finding procedure to come up to their decision. When states cannot disclose key domestic documents during the investigation, the Court dispatches its own judges to hear witnesses on the ground (Leach 2013).

Additionally, successful implementation of human rights treaty in Europe can also be attributed to the performance of Committee for the Prevention of Torture (CPT). Inspired by UN Convention Against Torture (CAT), CPT has significantly improved the treatment of people in European prison by building dialogue with the states (Leach 2013). It also creates public statements highlighting human rights violation of uncooperative states such as in the case of Turkey and Russia (Council of Europe 1992, 1996, 2001, 2003, 2007).

Meanwhile the Inter-American Human Rights System adopts two different kinds of regional human rights mechanisms. The Inter-American Commission of Human Rights is based on Organization of American States (OAS) Charter and 1948 American Declaration of the Rights and Duties of Man, and the Inter -American Court

\footnotetext{
8 The notion of ECHR as a living instrument have been acknowledged in many case laws such as Tyrer vs United Kingdom (1978), Marckx v. Belgium (1979), and more recently Magyar Helsinki Bizottság v. Hungary (2016).
} 
of Human Rights is based on the legally binding American Convention on Human Rights that entered into force in 1978 (Universal Rights Group n.d.).

The Court interprets the Convention holistically, restricting states interpretation that limits the citizens' freedom and helps socialize international human rights law into the domestic system (Sandoval 2013; Universal Rights Group n.d.). Concurrently, the Commission employs multifaceted approach and have quasi-judicial powers. It has thematic rapporteurships that monitor OAS' states compliance with specific human rights treaties Its reporting mechanism has significantly improved over the years, with increasing number of thematic country reports since 1998 addressing specific problem that affects particular country or OAS as a whole (Sandoval 2013). Therefore, having both charter-based Commission and treaty-based Court as the regional human rights mechanisms expands the scope of human rights protection to all of OAS states.

\section{Regional Body or Intergovernmental Organization}

Scholars define intergovernmental organizations (IGO) as formal entities with three or more sovereign member states and a "permanent secretariat or other indication of institutionalization such as headquarters and/or permanent staff" (Pevehouse et al. 2005, pp. 9-10). An IGO has to have "sufficient organizational structure and autonomy to provide formal, ongoing, multilateral processes of decision-making between states, along with the capacity to execute the collective will of their members (states)" (Volgy et al. 2008, p. 839). IGOs are formal institutions developed by states to help organize and coordinate policies at the international level and promote effective action at the domestic level. Regional bodies or intergovernmental organization can act as a socializing agent to facilitate the diffusion of international human rights law into domestic practices, by translating the law using local language and adjust the socialization process according to local cultural values. Therefore, they hold an important role in ensuring their member states implement the treaties effectively.

ASEAN is the primary international governmental organization in the Southeast Asian region. ASEAN was created to manage the stability of the region as well as to reinforce national and regional resilience (Acharya 1991; Solingen 1999; Ba 2009). Furthermore, the association emphasized more on economic development in the region through building the relationship between head of the nations (Leifer 1973; Pollard 1970). ASEAN, with more consensus-based, non-interference approach, dubbed the "ASEAN Way," may have successfully protect the peace and stability of Southeast Asia region. However, in the scope of human rights, ASEAN fails to make progress. ASEAN is seen as a weak socializing agent to mediate international human rights law with domestic practices because that human rights violations still flourished in the region. The consensus-based approach increases the amount of veto players at the intergovernmental level, which gives authoritative governments more power within the institution to prevent further strengthening of human rights implementation. The ASEAN Way also influences ASEAN to not interfere with domestic matters of each member. As ASEAN leaders often emphasized how human rights issue in each country is their own internal matter (Douglas and Douglas 1996; Khan 
Ghumro et al. 2019), the body does not impose punitive sanction to members that violate human rights abuse, as long as it does not threaten the stability of the region.

It also has been delivering weak rhetoric action to improve its members human rights records. This past decade, even with heavy international pressures, such as in the case of Myanmar, ASEAN efforts only consists of the use of language and public pronouncement to pressure Myanmar to stop the human rights abuses (Davies 2012). Rhetoric action emphasizes more in communication of each parties and convinces each other without material rewards or punishment (Risse 1999).

Moreover, all the rhetorical action representing by those public pronouncements have been sending contradictory messages instead of strengthening ASEAN position in defending human rights. For example, after the Dutch government's decision to deny Myanmar's economic minister a visa for the 6th Asia-Europe Meeting in Rotterdam in September 2005, ASEAN's economic ministers refused to attend the meeting as "a matter of principle" (Than 2006). This contradicted ASEAN's stance as at the same time ASEAN was critiquing Myanmar over the chairmanship issue (Petersson 2006). Therefore, these weak rhetorical actions and ASEAN's lack of judicial power to prevent human rights violations impede ASEAN response to tackle human rights problems effectively.

In contrast to ASEAN, the European Union (EU) and Council of Europe $(\mathrm{CoE})$ impose more strict regulation regarding human rights compliance of its member states. All the member states of EU have ratified the core UN human rights treaties, as EU requires members to comply with certain human right treaties to be considered for membership. This coercive strategy is associated with greater success in encouraging better protection of human rights in the region (Hafner-Burton 2005, 2009).

Also, the general principles of law EU must not infringe on any human rights law, and legislative proposals must first be examined through a human rights impact assessment (European Commission 2010). In addition, veto players are less important in the subsidiary EU agreements because non-consensus rules apply to decision-making. Only changes to the original EU treaties require unanimity. Incompliance to treaties and abuses of human rights are dealt with through punitive sanctions imposed by the Council of Europe. This systematic court and strict jurisdiction increase the efficacy of the treaties of human rights.

In addition to the regional human rights mechanisms mentioned previously, Council of Europe has also been encouraging the creation of NHRIs across the continent and their cooperation with EU institutions (Council of Europe 1997). CoE has also played an indispensable role in incorporating NHRIs through trainings, information session and facilitation of annual meetings in domestic and regional efforts to implement human rights treaty in the region (Lacatus 2019). Thus, it is important to acknowledge this collaborative role of regional body in the West that is currently missing in Southeast Asia.

Meanwhile in the Americas, the Organization of American States (OAS) also exert significant power in the advancement of human rights in the region (Sandoval 2013). In order to implement human rights treaty successfully, OAS similar to $\mathrm{EU}$ and $\mathrm{CoE}$ created human rights initiatives focusing on judicial settlement and are closer to the ground in comparison to the United Nations, giving them more 
advantage in socializing international human rights law in domestic level (Mégret and Alston 2020).

\section{Civil society}

Civil society is defined as a collective of people or organizations that is independent from the government or formal structures of the state (Woods 1992; Habermas 1991; Mitoma 2008). Historically, civil society acted as a counterbalance to "semifeudal institutions" that dominated the politics in the eighteenth-nineteenth century (Woods 1992). Regarding the scope of human rights issue, civil society continues to maintain that position, comprised of local and international non-governmental organizations (NGOs), grassroots organizations, international organizations such as the UN, as well as the ensemble of politically active and aware citizen of the state (Boulding and Nelson-Núñez 2014; Neumayer 2005; Tan 2011).

Since the civil society acts as a counterbalance to the state, stronger civil societies maintain the capability to exert pressure on governments and institutions to help ensure compliance of human rights treaties. Generally speaking, a strong civil society is measured by a high number of people participating in international non-governmental organizations (INGOs) or NGOs (Neumayer 2005), which creates more international linkages leading to larger transnational advocacy networks (TANs) pressuring government compliance (Hafner-Burton and Tsutsui 2005; Risse et al. 1999; Schmitz and Sikkink 2002).

TANs include international and domestic NGOs, other civil society groups, as well as media that are committed to the same goal of improving human right conditions. While TANs sometime help implement human rights improvements, they also provide a gateway for individuals to learn about human rights and be more actively involved (Tsutsui and Wotipka 2004). Sometimes, civil society organizations act as "norm entrepreneurs," introducing new norms or frames around norms within a particular institution or society (Finnemore and Sikkink 1998). As Wapner (2002) pointed out, participation in international and domestic NGOs create "collaboration and public spiritedness inside the organization," while also promoting "cooperation and social solidarity at the global level." In addition to that, Boli and Thomas (1997) argued that international NGOs empower civil society in a state by creating global standards and socialize them to the local communities. Thus, public participation in NGOs reflects the strength of one state's civil society (Tsutsui and Wotipka 2004).

Additionally, civil society organizations are the backbone of reporting mechanisms of human rights treaty in the global level. Civil society organizations are parts of the Council on Human Rights of the United Nations, and they submit shadow reports to relevant treaty bodies (Mégret and Alston 2020). The work and energy of civil society organizations undoubtedly are significant to the development of international human rights regime and its successful treaty implementation.

The developed countries of the West have stronger civil society than the less wealthy developing nations, shown by the substantial number of civilians participating in Human Rights International NGOs (HRINGOs). Tsutsui and Wotipka (2004) analyzed that from 1978 to 1998 , Western countries dominated the top 10 spots of 
HRINGOs membership, while developing Southeast Asian nations, such as Brunei, Laos and Cambodia, were among the bottom 10 countries. More supporting policies, training, and funding available in the West played a role in nurturing the growth of civil society. As noted earlier, lack of partnership and consultation with civil society led to critiques of ASEAN Human Rights Declaration (AHRD), one of the main human rights instruments in the region. Furthermore, limited participation of civil society in ASEAN is also shown by the fact that AICHR has accredited only 30 Civil Society Organizations in Southeast Asia to work side by side implementing more effective human rights treaties (ASEAN 2018).

\section{Political stability}

Scholars defined political stability/instability of a country by assessing the longevity or duration of a government of that country (Hurwitz 1973; Blondel 1968; Taylor and Herman 1971). Supporting this view, Alesina et al. (1996, p. 191) defines political instability as "the propensity of a change in the executive power, either by constitutional or unconstitutional means." Furthermore, Hurwitz (1973) also argued that scholars commonly associate political stability with the absence of civil conflict or violence. Politically stable states have peaceful and law-abiding society, where the socio-political changes are the result of "institutionalized procedures" and not the result of conflict of aggression (Hurwitz 1973). In addition, Feierabend and Feierabend (1966) associate political stability/instability to "the degree or the amount of aggression directed by individuals or group within the political system against other groups."

In his research, Rummel (1963) stated nine measures of internal conflict such as assassination, strike, guerrilla war, major government crisis, purge, riot, demonstration, revolution, and number killed in domestic violence that creates political instability. These conflicts often result in higher levels of human rights violations due to government policing or persecution of those individuals and groups responsible for the instability. This is particularly relevant to civil rights where often civil liberties are suspended in the event of uprisings against the state. Some international treaties allow for suspension of the terms of a treaty in the face of such unstable conditions domestically because it can undermine the state, and failed states, without any protections from governments may result in further human rights violations.

Political instability exists in the Southeast Asian region as some of the countries face challenges from separatist groups, sometimes provoking civil war against the government (Caballero-Anthony 1995; Renshaw 2013). Thus, for the government, maintaining national stability and preventing civil unrest requires use of resources, which can be used for human rights treaties implementation (Keith 1999). In addition, human rights violations often result from repression directed by the government to "keep the nation stable" (Davenport 1995; Hathaway 2002; Poe and Tate 1994; Poe et al. 1999).

Similarly, the West also faces challenges maintaining human rights while ensuring security. To preserve democracy, political instability, and potential challenges to the governing bodies within Western nations also presents challenges just as in 
Southeast Asian nations. Political terrorism, designed to undermine the state may result in suspension of some civil liberties, such as the implementation of the Patriot Act in the United States and other provisions that increased the ability of the government to spy on citizens, reducing privacy and expression rights (Foot 2005; Ignatieff 2005).

Nevertheless, the 2017 Global Report from Center for Systemic Peace has showed that the North Atlantic region, comprises of United States, Canada, and Western European countries are the least fragile region in the world, indicating the least occurrences of political violence (Marshal and Elzinga-Marshall 2017). Comparing the result to Southeast Asian countries, the Western states average score of the most recent 2018 State Fragility Index is 0.8, while the Southeast Asian countries average score is 9.2, with Myanmar having the highest score (Marshall and Elzinga-Marshall 2018). Lower score indicates lower state fragility and instability that can be associated to lower risk of open warfare and higher level of well-being in the region (Marshal and Elzinga-Marshall 2017). Thus, although both regions face challenges in maintaining their political stability, the data showed that the Western states are more politically stable than the Southeast Asian states. This significant difference plays a role in creating more effective human rights treaty implementation.

\section{Conclusion}

There are seven factors that may vary between nations that influence their ability to implement international human rights agreements domestically: political capacity, economic power, national human rights institutions, regional human rights commissions and courts, regional bodies and intergovernmental associations, civil society, and political stability. Each of these varies between western nations and Southeast Asian nations, which affect their propensity to implement human rights treaties effectively. In general ASEAN nations lack behind efforts of Western nations due to their lack of human rights institutions, and regional human rights courts as well as intergovernmental associations. Within the ASEAN nations, however, there is greater variation among the states in terms of the strength of civil society, political stability, and economic power.

After reviewing the literature on the differences between Southeast Asian and Western nations, a wide range of factors may influence the differences in implementation of human rights between the regions. In order to evaluate the influence of human rights treaties, it is important to control for the seven factors discussed above in case studies and quantitative analysis. Since there is still no consensus on the effects of human rights treaties, this research helps scholars understand the other factors that may influence the results in their studies.

Although all seven factors are essential to the implementation of human rights treaty, NHRIs, regional human rights mechanisms (courts and commissions) and regional body/IGOs are the three most important ones. NHRIs hold government responsible to their action while bridging local civil society organizations. It also works with citizens in individual levels. Its power to receive complaints from 
individuals helps to identify human rights violation cases in grassroot level, which are often overlooked by national or regional court system.

Meanwhile, regional body/IGOs and regional human rights mechanisms are interlinked. As we have seen in the case of Southeast Asian countries and the Western countries, it is not possible to conceive a thorough and effective human rights mechanisms without strong human rights foundation in the regional body/ IGOs. Regional body/IGOs can improve its member states' human rights record by establishing punitive sanction or incentives for compliance to human rights treaty. Stronger regional body/IGOs can exert pressure to its member to achieve regional agreement to human rights treaties and minimize the influence of non-pro human rights governments. Thus, it is important for ASEAN member states to focus on the human rights agenda of the region. Stronger rhetorical action towards egregious human rights violations can be combined with rigorous supervision from AICHR. More independent representatives in these commissions are also essential for better treaty implementation. As a stronger regional body/IGO creates better performing regional human rights mechanisms and enables NHRIs to work optimally, these three factors are indispensable towards more effective human rights treaty implementation. Following this, it is possible to improve Southeast Asian nations' human rights compliance by focusing on these most crucial factors.

Data availability Data sharing is not applicable to this article as no new data were created or analyzed in this study.

\section{Compliance with ethical standards}

Conflict of interest Authors declared that they have no conflicts of interest, financial or otherwise.

\section{References}

Abbott KW, Snidal D (2000) Hard and soft law in international governance. Int Org 54(3):421-456

Abrams BA, Lewis KA (1993) Human rights and the distribution of US foreign aid. Public Choice $77: 815-821$

Acharya A (1991) The Association of Southeast Asian Nations: 'security community' or 'defence community'? Pac Affairs 64(2):159-178

Acharya A (1997) Ideas, identity, and institution - building: from the 'ASEAN way' to the 'Asia - Pacific way'? Pac Rev 10(3):319-346. https://doi.org/10.1080/09512749708719226

Alesina A, Ozler S, Roubini N, Swagel P (1996) Political instability and economic growth. J Econ Growth 1:189-211

Alexander KW (2000) NATO's intervention in Kosovo: the legal case for violating Yugoslavia's National Sovereignty in the absence of security council approval. Houst J Int Law 22(2):403-450

Amnesty International (1977) Indonesia: an amnesty international report. Amnesty International Publications, London

Amnesty International (2016) Australia: appalling abuse, neglect of refugees on Nauru. Amnesty International, London

Amnesty International (2018) Philippines 2017/2018. Amnesty International, London

Amnesty International (2020) USA: the world is watching mass violations by US Police of black lives matter protesters' rights. Amnesty International, London

An-Na'im AA (1999) The cultural mediation of human rights: the Al-Arqam CASE in Malaysia. In: Bauer JR, Bell DA (eds) The East Asian challenge for human rights. CambridgeUniversity Press, Cambridge, NY, pp 147-168 
Apodaca C, Stohl M (1999) United States human rights policy and foreign assistance. Int Stud Quart 43(1):185-198. https://doi.org/10.1111/0020-8833.00116

ASEAN (2012) ASEAN human rights declaration. https://asean.org/asean-human-rights-declaration/

ASEAN (2018) ASEAN human rights body to enhance collaboration with civil society. https://asean.org/ asean-human-rights-body-enhance-collaboration-civil-society/

ASEAN Secretariat (2009) ASEAN intergovernmental commission on human rights (terms of reference) one vision, one identity, one community."

Aspinall E (2010) The irony of success. J Democ 21(2):20-34. https://doi.org/10.1353/jod.0.0157

Axelrod R (1997) The dissemination of culture: a model with local convergence and global polarization. J Conflict Resolut. https://doi.org/10.1177/0022002797041002001

Ba AD (2009) Negotiating East and Southeast Asia: region, regionalism, and the Association of Southeast Asian Nations. Stanford University Press, Redwood city, CA

Baer D (2012) Keynote address to the US-ASEAN Symposium on the ASEAN Human Rights Mechanism. https://2009-2017.state.gov/j/drl/rls/rm/2012/201210.htm

Balnaves H, Burkle EM, Erkan J, Fischer D (2020) European populism in the European Union: results and human rights impacts of the 2019 parliamentary elections. Global Campus Hum Rights J 4:176-200

Barnds WJ (1995) Human rights and US policy towards Asia. In: Tang JT-H (ed) Human rights and international relations in the Asia Pacific in the Asia Pacific. Pinter, New York, pp 71-82

Barreto J-M (ed) (2013) Human rights from a third world perspective: critique, history and international law. Cambridge Scholars Publishing, Newcastle upon Tyne

Baxi U (2007) The future of human rights, 3rd edn. Oxford University Press, Oxford

Beetham D (1999) Democracy and human rights. Polity Press, Cambridge

Beitz CR (2001) Human rights as a common concern. Am Polit Sci Rev 95(2):269-282

Bhambra GK (2007) Rethinking modernity: postcolonialism and the sociological imagination. Palgrave MacMillan, Basingstoke

Blanton SL (1999) Instruments of security or tools of repression? Arms imports and human rights conditions in developing countries. J Peace Res 36(2):233-244. https://doi.org/10.1177/0022343399 036002006

Blanton SL, Blanton RG (2007) What attracts foreign investors? An examination of human rights and foreign direct investment. J Polit 69(1):143-155. https://doi.org/10.1111/j.1468-2508.2007.00500.x

Blondel J (1968) Party systems and patterns of government in western democracies. Can J Polit Sci $1(2): 180-203$

Boli J, Thomas GM (1997) World culture in the world polity: a century of international non-governmental organization. Am Sociol Rev 62(2):171-190

Boulding CE, Nelson-Núñez J (2014) Civil society and support for the political system in times of crisis. Latin Am Res Rev 49(1):128-154

Brackney WH (2013) Human rights and the world's major religions: condensed and updated edition. ABC-CLIO, Santa Barbara

Brotton J (2002) The renaissance bazaar: from the silk road to Michelangelo. Oxford University Press, Oxford

Brown We (2004) The most we can hope for ...': human rights and the politics of fatalism. The South Atlantic Quarterly 103(2):132-146. https://doi.org/10.4324/9780203814031

Caballero-Anthony M (1995) Human rights, economic change \& political development. In: Tang JT-H (ed) Human rights and international relations in the Asia Pacific in the Asia Pacific. Pinter Publisher, New York, pp 39-53

Campbell T (2011) Rights: a critical introduction. Routledge, New York

Caramani D (2017) Will vs. reason: the populist and technocratic forms of political representation and their critique to party government. Am Polit Sci Rev 111(1):54-67

Cardenas S (2003) Emerging global actors: the United Nations and National Human Rights Institutions. Global Govern 9:23-42

Carleton D, Stohl M (1987) The role of human rights in U.S foreign assistance policy: a critique and reappraisal. Am J Polit Sci 31(4):1002-1018

Carver R (2004) Performance and legitimacy: national human rights institutions. International Council on Human Rights Policy, Versoix

Carver R (2011) One NHRI or many? how many institutions does it take to protect human rights? - lessons from the European experience. J Hum Rights Pract. https://doi.org/10.1093/jhuman/hur005

Center for Systemic Peace (2019) INSCR data page. http://www.systemicpeace.org/inscrdata.html 
Cerna Christina M (1994) Universality of Human Rights and Cultural Diversity: implementation of Human Rights in Different Socio-Cultural Contexts. Hum Rights Q 16:740

Chan J (1995) The Asian challenge to universal human rights: a philosophical appraisal. In: Tang JT-H (ed) Human rights and international relations in the Asia Pacific. Printer, New York, pp 25-38

Chayes A, Chayes AH (1993) On compliance. International Organization 47(2):175-205

Chayes A, Chayes AH (1998) The new sovereignty. Harvard University Press, Cambridge

Choi SW, Kim Y, Ebner D, James P (2020) Human rights institutionalization and US Humanitarian Military intervention. Int Interact 46(4):606-635. https://doi.org/10.1080/03050629.2020.1758694

Cingranelli D, Pasquarello TE (1985) Human rights practices and the distribution of U.S Foreign Aid to Latin American Countries. Am J Polit Sci 29(3):539-563

Cingranelli D, Richards DL, Clay KC (2014) The Cingranelli-Richards (CIRI) human rights dataset. http://www.humanrightsdata.com/

Ciorciari JD (2012) Institutionalizing human rights in Southeast Asia. Hum Rights Q 34(3):695-725

Clapham A (2015) Human rights: a very short introduction. Oxford University Press, Oxford

Clarke G (2012) The evolving ASEAN human rights system: the ASEAN human rights declaration of 212. Northw J Int Hum Rights 11(1):1-27

Cogburn DL, Reuter TK (2017) Making disability rights real in Southeast Asia. Lexington Books, Lanham

Cohen J (2004) Minimalism about human rights the most we can hope for. J Polit Philosophy 12(2):190-213

Cole WM (2012) Institutionalizing shame: the effect of human rights committee rulings on abuse, 19812007. Soc Sci Res 41(3):539-554. https://doi.org/10.1016/j.ssresearch.2011.12.003

Cole WM (2015) Mind the gap: state capacity and the implementation of human rights treaties. Int Org 69(2):405-441. https://doi.org/10.1017/S002081831400040X

Cole WM, Ramirez FO (2013) Conditional decoupling: assessing the impact of national human rights institutions, 1981 to 2004. Am Sociol Rev 78(4):702-725. https://doi.org/10.1177/0003122413 492762

Gibney M, Cornett L Wood, R, Haschke P, Arnon D, Pisano A, Barret G (2019) The Political Terror Scale 1976-2018. http://www.politicalterrorscale.org/

Council of Europe (1992) European Committee for the prevention of torture and inhuman or degrading treatment or punishment (CPT): public statement on Turkey. CPT/Inf (93)1. https://www.coe.int/ en/web/cpt/turkey

Council of Europe (1996) European Committee for the prevention of torture and inhuman or degrading treatment or punishment (CPT): public statement on Turkey. CPT/Inf (96)34. https://www.coe.int/ en/web/cpt/turkey

Council of Europe (1997) Establishment of independent national institutions for the promotion and protection of human rights. Recommendation no R(97)14. https://rm.coe.int/16804fecf5

Council of Europe (2001) European Committee for the prevention of torture and inhuman or degrading treatment or punishment (CPT): public statement concerning the Chechen Republic of the Russian Federation. CPT/Inf (2001)15. https://www.coe.int/en/web/cpt/russian-federation

Council of Europe (2003) European Committee for the prevention of torture and inhuman or degrading treatment or punishment (CPT): public statement concerning the Chechen Republic of the Russian Federation. CPT/Inf (2003)33. https://www.coe.int/en/web/cpt/russian-federation

Council of Europe (2007) European Committee for the prevention of torture and inhuman or degrading treatment or punishment (CPT): public statement concerning the Chechen Republic of the Russian Federation. https://www.coe.int/en/web/cpt/russian-federation

Cousin G (2011) Rethinking the concept of 'western'. High Educ Res Dev 30(5):585-594. https://doi. org/10.1080/07294360.2011.598449

Cribb R (1990) Problems in the historiography of the killings in Indonesia. In: Cribb R (ed) The Indonesian killings of 1965-1966. Centre of Southeast Asian Studies Monash University, Clayton, pp $1-43$

Davenport C (1995) Multi-dimensional threat perception and state repression: an inquiry into why states apply negative sanctions. Am J Polit Sci 39(3):683-713. https://doi.org/10.2307/2111650

Davies Mathew (2012) The perils of incoherence: ASEAN, Myanmar and the avoidable failures of human rights socialization? Contemp Southe Asia A 34(1):1-22. https://doi.org/10.1353/csa.2012.0006

Davies M (2014a) An agreement to disagree: the ASEAN human rights declaration and the absence of regional identity in Southeast Asia. J Curr Southe Asian Affairs 33(3):107-129 
Davies M (2014b) States of compliance?: global human rights treaties and ASEAN member states. J Hum Rights 13(4):414-433. https://doi.org/10.1080/14754835.2014.886949

De Beco G (2007) National human rights institutions in Europe. Human Rights Law Review 7(2):331370. https://doi.org/10.1093/hrlr/ngm004

Dembour MB (2010) What are human rights? Four schools of thought. Hum Rights Q 32(1):1-20. https ://doi.org/10.1353/hrq.0.0130

Derrida J (2005) On cosmopolitan and forgiveness, 3rd edn. Routledge, New York

Devetak R (2004) In fear of refugees: the politics of border protection in Australia. Int J Hum Rights 8(1):101-109. https://doi.org/10.1080/1364298042000212565

Donnelly J (1986) International human rights: a regime analysis. Int Org 40(3):599-642

Donnelly J (2013) Universal human rights in theory and practice. Cornell University Press, London

Donnelly J, Whelan DJ (2017) International human rights. Hachette, London

Douglas SA, Douglas SU (1996) Economic implications of the U.S.-ASEAN discourse on human rights. Pac Affairs 69(1):71-87. https://doi.org/10.2307/2760874

Douzinas C (2007) Human rights and empire: the political philosophy of cosmopolitanism. Routledge, New York

Druce SC (2019) Political impasse vs economic development: a history and analysis of the West Papua conflict in Indonesia. In: Oishi M (ed) Managing conflicts in a globalizing ASEAN: incompatibility management through good governance. Springer, New York, pp 89-116

Edmundson WA (2012) An introduction to rights. Introd Rights. https://doi.org/10.1017/CBO9780511 610936

Egan S (2020) Reform of the UN human rights treaty body system. In Frédéric M, Philip A (eds) The United Nations and human rights: a critical appraisal

Eldridge P (2002) Human rights in Post-Suharto Indonesia. Brown J World Affairs 9(1):127-139

Emmerson DK (2005) Security, community, and democracy in Southeast Asia: analyzing ASEAN. Jpn J Polit Sci 6(2):165-185. https://doi.org/10.1017/S1468109905001829

Espenido Gil (2018) Philippines' war on drugs: its implications to human rights in social work practice. J Hum Rights Soc Work 3:138-148

European Commission (2010) Communication from the commission: strategy for the effective implementation of the charter of fundamental rights by the European Union. Brussels

European Court of Human Rights (2020) Composition of the Court. https://echr.coe.int/Pages/home. aspx? $=$ court/judges\&c

European Network of National Human Rights Institutions (ENNHRI) (nd) Our members. http://ennhr i.org/our-members/ Accessed 31 July 2020

European Union (2019) EU annual report on human rights and democracy in the world 2019 country updates

Feierabend IK, Feierabend RL (1966) Aggressive behaviors within polities. J Conflict Resol 10(3):249-271

Fine S, Dennison S, Gowan R (2019) Policy brief false moves: migration and development aid. European Council on Foreign Relations. https://www.ecfr.eu/page/-/false_moves_migration_and_devel opment_aid.pdf

Finnemore M (1996a) Constructing norms of humanitarian intervention. In: The culture of national security: norms and identity in world politics, vol xv. Columbia University Press, New York

Finnemore M (1996b) Norms, culture, and world politic: insights from sociology's institutionalism". Int Org 50(2):325

Finnemore M, Sikkink K (1998) International norm dynamics and political change. Int Org 52(4):887-917

Foot R (2005) Collateral damage: human rights consequences of counterterrorist action in the AsiaPacific. Int Affairs 81(2):411-425

Forsythe DP (1985) The United Nations and Human Rights, 1945-1985. Polit Sci Q 100(2):249-269

Forsythe DP (1991) The internationalization of human rights. Lexington Books, Lexington

Fournier J (2010) Reservations and the effective protection of human rights. Goett J Int Law 2:437. https ://doi.org/10.3249/1868-1581-2-2-Fournier

Franck TM (1988) Legitimacy in the international system. Am J Int Law 82:705

Freeman M (1995) Human rights: Asia and the west. In: Tang JT-H (ed) Human rights and international relations in the Asia Pacific. Pinter Publisher, New York, pp 13-24

Freeman M (2013) Universalism of human rights and cultural relativism. In: Sheeran S, Rodley N (eds) Handbook of international human rights law. Routledge, London, pp 49-61 
Fukuyama F (2013) What is governance? Governance 26(3):347-368. https://doi.org/10.1111/gove.12035 Galston WA (2018) The populist challenge to liberal democracy. Democracy 29(2):5-19

Gewirth A (1996) The community of rights. The University of Chicago Press, London

Ghai Y (1995) Asian perspectives on human rights. In: Tang JT-H (ed) Human rights and international relations in the Asia Pacific. Pinter Publisher, New York, pp 38-54

Ginbar Y (2010) Human rights in ASEAN-setting sail or treading water? Hum Rights Law Rev 10(3):504-518. https://doi.org/10.1093/hrlr/ngq024

Global Alliance of National Human Rights Institutions (2019) Accreditation Status as of 27 November 2019. https://nhri.ohchr.org/EN/AboutUs/GANHRIAccreditation/Pages/default.aspx

Goodale M (2009) Surrendering to Utopia: an anthropology of human rights. Stanford University Press, Standford

Goodman R, Jinks D (2003) Measuring the effects of human rights treaties. EJIL 14(1):171-183

Goodman R, Jinks D (2004) How to influence states: socialization and international human rights law. Duke Law J 54(3):621-703

Gourevitch P (2002) Domestic politics and international relations. In: Carlsnaes W, Risse-Kappen T, Simmons BA (eds) Handbook of international relations. Sage Publications, London

Green J (1989) The Philippines: United States Policy and Allegations of human rights abuses under aquino. Harv Hum Rights J 2:187-196

Griffin J (2008) On human rights. Oxford University Press, Oxford

Groves S (2013) U.S. National Human Rights Institution: a bad idea. https://www.heritage.org/report/usnational-human-rights-institution-bad-idea

Haas M (2013) International human rights. Routledge, London

Habermas J (1991) The structural transformation of the public sphere. The MIT Press, Cambridge

Habermas J (2015) Between facts and norms: contributions to a discourse theory of law and democracy. Polity Press, Cambridge

Hadiprayitno II (2010) Defensive enforcement: human rights in Indonesia. Hum Rights Rev 11(3):373399. https://doi.org/10.1007/s12142-009-0143-1

Hadiz VR, Robinson Richard (2013) The political economy of oligarchy and the reorganisation of power in Indonesia. Indonesia 96:35-57

Hafner-Burton EM (2005) Trading human rights: how preferential trade agreements influence government repression. Int Org. https://doi.org/10.1017/S0020818305050216

Hafner-Burton EM (2008) Sticks and Stones: naming and shaming the human rights enforcement problem. Int Org 62(4):689-716. https://doi.org/10.1017/S0020818308080247

Hafner-Burton EM (2009) Forced to be good: why trade agreements boost human rights. Cornell University Press, Ithaca

Hafner-Burton EM, Tsutsui K (2005) Human rights in a globalizing world: the paradox of empty promises. Am J Sociol 110(5):1373-1411. https://doi.org/10.1086/428442

Hafner-Burton EM, Tsutsui K (2007) Justice lost! the failure of international human rights law to matter where needed most. J Peace Res 44(4):407-425. https://doi.org/10.1177/0022343307078942

Hamm BI (2001) A human rights approach to development. Hum Rights Q 23(4):1005-1031

Harpur Paul (2012) Embracing the new disability rights paradigm: the importance of the convention on the rights of persons with disabilities. Disabil Soc 27(1):1-14. https://doi.org/10.1080/09687 599.2012.631794

Hathaway OA (2002) Do human rights treaties make a difference? Yale Law J 11(8):1935-2042

Hathaway OA (2003) The cost of commitment. Standford Law Rev 55(5):1821-1862

Hathaway OA (2005) The promise and limits of the international law of torture. In: Hathaway OA, Koh $\mathrm{HH}$ (eds) Foundations of international law and politics. Foundation, New York, pp 228-237

Hathaway OA (2007) Why do countries commit to human rights treaties? J Conflict Resolut 51(4):588-621

Henkin L (1979) How nations behave: law and foreign policy. Columbia University Press, New York

Hill DW (2010) Estimating the effects of human rights treaties on state behavior. J Politics 72(4):11611174. https://doi.org/10.1017/S0022381610000599

Howard RM, Carey HF (2004) Independent judiciary necessary for democracy? Judicature 87(6):284-291

Hui VT (2005) War and state formation in ancient China and early modern Europe. Cambridge University Press, Cambridge

Human Rights Watch (2012) Civil Society denounces adoption of flawed ASEAN human rights declaration. https://www.hrw.org/news/2012/11/19/civil-society-denounces-adoption-flawed-asean-human -rights-declaration

\section{SN Social Sciences}


Human Rights Watch (2017) 'License to kill': Philippine police killings in Duterte's 'war on drugs.' Human Rights Watch. https://www.hrw.org/report/2017/03/02/license-kill/philippine-police-killi ngs-dutertes-war-drugs

Human Rights Watch (2018) Philippines: events of 2017. https://www.hrw.org/world-report/2018/count ry-chapters/philippines

Human Rights Watch (2019a) Nothing left in the cupboards: austerity, welfare cuts, and the right to food in the UK. Human Rights Watch. https:/www.hrw.org/report/2019/05/20/nothing-left-cupboards/ austerity-welfare-cuts-and-right-food-uk

Human Rights Watch (2019b) World report 2019. https://www.hrw.org/world-report/2019

Human Rights Watch (2020a) Covid-19 fueling anti-Asian racism and xenophobia worldwide: national action plans needed to counter intolerance. Human Rights Watch. 2020. https://www.hrw.org/ news/2020/05/12/covid-19-fueling-anti-asian-racism-and-xenophobia-worldwide

Human Rights Watch (2020b) 'He's never coming back': people with disabilities dying in Western Australia's Prisons. Human Rights Watch. https:/www.hrw.org/report/2020/09/15/hes-never-comin g-back/people-disabilities-dying-western-australias-prisons

Human Rights Watch (2020c) UK: children in England going hungry with schools shut-uneven UK approach for Covid-19 doesn't guarantee children's right to food. Human Rights Watch. https:// www.hrw.org/news/2020/05/27/uk-children-england-going-hungry-schools-shut

Hurwitz L (1973) Contemporary approaches to political stability. Compar Politics 5(3):449-463. https:// doi.org/10.2307/421273

Ignatieff M (1999) The lesser evil: political ethics in an age of terror. Princeton University Press, Princeton

Ignatieff M (2003) Human rights as politics and idolatry. Princeton University Press, Princeton

Ignatieff M (2005) Introduction: American exceptionalism and human rights. Princeton University Press, Princeton

Iida K (1993) When and how do domestic constraints matter? Two-level games with uncertainty. J Conflict Resolut 37(3):403-426. https://doi.org/10.1177/0022002793037003001

Inter-American Commission on Human Rights (2000) Rudolph Baptiste v. Grenada. Case 11.743 report no. $38 / 00$

Ishay Micheline (2008) The history of human rights: from ancient times to the globalization era. University of California Press, Los Angeles

Jaggar A (ed) (2010) Thomas pogge and his critics. Polity Press, Cambridge

Jensen Steven L B (2016) The making of international human rights: the 1960s, decolonization and the reconstruction of global values. Cambridge University Press, New York

Jetschke A (1999) Linking the unlinkable? International norms and nationalism in Indonesia and the Philippines. In: Risse T, Ropp SC, Sikkink K (eds) The power of human rights: international norms and domestic change. Cambridge University Press, Cambridge, pp 134-171

Juwana H (2006) Human rights in Indonesia. Indon J Int Law 4:27

Kammen D, McGregor K (2012) Introduction: the contours of mass violence in Indonesia. In: Kammen D, McGregor K (eds) The contours of mass violence in Indonesia, 1965-1968. NUS Press, Singapore, pp 1-21

Kamuf Ward J, Catherine CF (2019) How the Trump administration's efforts to redefine human rights threaten economic, social, and racial justice. HRLR ONLINE 4(1):1-32

Karan PP (2004) The non-western world: environment: development and human rights. Routledge, London

Katsumata H (2009) ASEAN and human rights: resisting western pressure or emulating the west? Pac Rev 22(5):619-637. https://doi.org/10.1080/09512740903329731

Katsumata H (2011) Mimetic adoption and norm diffusion: 'western' security cooperation in Southeast Asia? Rev Int Stud 37:557-576. https://doi.org/10.1017/S0260210510000872

Kayess R, French P (2008) Out of darkness into light? Introducing the convention on the rights of persons with disabilities. Hum Rights Law Rev 8(1):1-34. https://doi.org/10.1093/hrlr/ngm044

Keith LC (1999) The United nations international covenant on civil and political rights: does it make a difference in human rights behavior? J Peace Res 36(1):95-118. https://doi.org/10.1177/00223 43399036001006

Kenny PD (2018) Populism in Southeast Asia. Cambridge University Press, Cambridge

Keohane RO (1984) After hegemony: cooperation and discord in the world political economy. Princeton University Press, Princeton 
Keohane RO (2015) After hegemony cooperation is still possible. International Spectator 50(4):92-94. https://doi.org/10.1080/03932729.2015.1079683

Khan G, Ali MP, Nizamani AR (2019) Coping with human rights challenge: a perspective from ASEAN. Asia Pacific 37:81-101

Koh HH (1997) Why do nations obey international law? Yale Law J 106(8):2599-2659

Koh T (2009) The negotiation process. In: Koh T, Manalo RG, Woon W (eds) The making of ASEAN charter. World Scientific Publishing, pp 47-66

Lacatus C (2019) Explaining institutional strength: the case of national human rights institutions in Europe and its neighbourhood. J Eur Public Policy 26(11):1657-1677. https://doi. org/10.1080/13501763.2018.1545795

Lauren PG (2011) The evolution of international human rights: visions seen. University of Pennsylvania Press, Philadephia

Leach P (2013) The European system and approach. In: Scott S, Nigel R (eds) Routledge handbook of international human rights law. Routledge, London, pp 407-425

Leach P (2017) Taking a case to the European court of human rights. Oxford University Press, Oxford

Lebovic JH, Voeten E (2006) The politics of shame: the condemnation of country human rights practices in the UNCHR. Int Stud Quart 50(4):861-888. https://doi.org/10.1111/j.1468-2478.2006.00429.x

Lebovic JH, Voeten E (2009) The cost of shame: International organizations and foreign aid in the punishing of human rights violators. J Peace Res 46(1):79-97

Leeds BA (1999) Domestic political institutions, credible commitments, and international cooperation. Am J Polit Sci 43(4):979-1002

Leifer M (1973) The Asean states: no common outlook. Int Affairs 49(4):600-607

Letsas G (2013) The ECHR as a living instrument: its meaning and legitimacy. In: Føllesdal A, Peters B, Geir Ulfstein (eds) Constituting Europe: The European court of human rights in a national, European and global context. Cambridge University Press, New York

Linton S (2008) ASEAN states, their reservations to human rights treaties and the proposed ASEAN commission on women and children. Hum Rights Q 30(2):436-493. https://doi.org/10.1353/ hrq.0.0010

Lupu Y (2015) Legislative veto players and the effects of international human rights agreements. Am J Polit Sci 59(3):578-594. https://doi.org/10.1111/ajps

Lutz EL, Sikkink K (2000) International human rights law and practice in Latin America. Int Org 54(3):633-659

MacIntyre A (2007) After virtue: a study in moral theory. University of Notre Dame Press, Notre Dame

Marshal MG, Elzinga-Marshall G (2017) Global report 2017: conflict, governance and state fragility. Vienna, VA

Marshall MG, Elzinga-Marshall G (2018) State fragility index and matrix. Center for Systemic Peace, Vienna

Mayer A (2017) Redefining rights: OIC attempts to reshape values in the UN Human Rights System. In: Chase AT (ed) Routledge handbook on human rights and the Middle East and North Africa. Routledge, London, pp 170-181

McAdam D, Tarrow S, Tilly C (2004) Dynamics of contention. Cambridge University Press, Cambridge

McDonnell D, Werner A (2020) International populism: the radical right in the European parliament. Oxford University Press, Oxford

McGregor K, Setiawan K (2019) Shifting from international to 'Indonesian' justice measures: two decades of addressing past human rights violations. J Contemp Asia 49(5):837-861. https://doi. org/10.1080/00472336.2019.1584636

Mearsheimer JJ (1994) The false promise of international institutions. Int Secur 19(3):5-49

Mechlem K (2009) Treaty bodies and the interpretation of human rights. Vanderbilt J Transnat Law 42:905

Meernik J, Krueger EL, Poe SC (1998) Testing models of U.S. foreign policy: foreign aid during and after the cold war. J Politics 60(1):63-85

Mégret F, Alston P (2020) The United Nations and human rights: a critical appraisal, 2nd edn. Oxford University Press, New York

Mende J (2019) Are human rights western-and why does it matter? A perspective from international political theory. J Int Polit Theory. https://doi.org/10.1177/1755088219832992

Merry SE (2006) Human rights and gender violence: translating international law into local justice. University of Chicago Press, Chicago 
Milner HV (1997) Interests, institutions, and information: domestic politics and international relations. Princeton University Press, Princeton

Milner WT (2002) Economic globalization and rights: an empirical analysis. In: Brysk A (ed) Globalization and human rights. University of California Press, Berkeley, pp 77-97

Mitchell RB (1993) Compliance theory: a synthesis. Rev Eur Compar Int Environ Law 2(4):327

Mitchell NJ, Mccormick JM (1988) Economic and political explanations of human rights violations. World Politics 40(4):476-498. https://doi.org/10.1017/S0021937100024837

Mitoma GT (2008) Civil society and international human rights: the commission to study the organization of peace and the origins of the UN Human Rights Regime. Hum Rights Q 30(3):607-630. https://doi.org/10.1353/hrq.0.0015

Moeckli D, White ND (2018) Treaties as 'living instruments.' In: Conceptual and contextual perspectives on the modern law of treaties, pp 136-171

Morales NJ (2018) Philippines Duterte tells U.N. Human Rights Expert: 'go to hell.' Reuters. https:// www.reuters.com/article/us-philippines-duterte-un/philippines-duterte-tells-u-n-human-right s-expert-go-to-hell-idUSKCN1IZ063?feedType $=$ RSS\&feedName=topNews

Moravcsik A (2000) The origins of human rights regimes: democratic delegation in postwar Europe. Int Org 54(2):217-252

Mower GA (1976) Human rights in Western Europe: progress and problems. Int Affairs 52(2):235-251

Munro J (2011) The relationship between the origins and regime design of the ASEAN intergovernmental commission on human rights (AICHR). Int J Hum Rights 15(8):1185-1214. https://doi. org/10.1080/13642987.2010.511996

Muntarbhorn V (2012) Development of the ASEAN human rights mechanism. https://doi. org $/ 10.2861 / 49347$

Muntarbhorn V (2013) The South East Asian system for human rights protection. In: Scott S, Nigel R (eds) Routledge handbook of international human rights law. Routledge, London, pp 467-481

Mutua Makau (2002) Human rights: a political and cultural critique. University of Pennsylvania Press, Philadephia

Narine S (1997) ASEAN and the ARF: the limits of the 'ASEAN way'. Asian Surv 37(10):961-978

Nash JC (2001) Mayan visions: the quest for autonomy in an age of globalization. Routledge, New York

Netipatalachoochote S, Ciacchi AC, Holzhacker Ronald (2020) National human rights institutions (Nhris) in Asean. Eur J Compar Law Govern 7(2):117-167. https://doi.org/10.1163/22134514-00702002

Neumayer E (2005) Do international human rights treaties improve respect for human rights? J Conflict Resolut. https://doi.org/10.1177/0022002705281667

Neumayer E (2007) Qualified ratification: explaining reservations to international human rights treaties. J Legal Stud 36(2):397-429. https://doi.org/10.1086/511894

Nkrumah K (1962) Towards colonial freedom: Africa in the struggle against world imperialism. PANAF, London

Nussbaum M, Sen A (eds) (1993) The quality of life. Clarendon Press, Oxfords

OHCHR (2010) National Human Rights Institutions: history, principles, roles and responsibilities professional training series no. 4 (Rev.1). United Nations Publication, New York. https://doi. org/10.4135/9781473909335.n38

OHCHR (n.d.) Regional human rights systems in other parts of the world: Europe, the Americas and Afric. http://bangkok.ohchr.org/programme/other-regional-systems.aspxa. Accessed 30 Mar 2020

Opsahl T (1995) The human rights committee. In: Philip A (ed) The United Nations and human rights: a critical appraisal. Oxford University Press, Oxford, pp 369-443

OSCE (2015) Statement by United States of America on National Human Rights Institutions. https:// www.osce.org/odihr/161251

Panikkar R (1982) Is the notion of human rights a western concept? Diogenes 30(120):75-102. https:// doi.org/10.1177/039219218203012005

Pegram T (2010) Diffusion across political systems: the global spread of national human rights institutions. Hum Rights Q 32(3):729-760

Pernia RA (2019) Human rights in a time of populism: Philippines under Rodrigo Duterte. Asia-Pac Soc Sci Rev 19(3):56-71

Perry MJ (1998) The idea of human rights: four inquiries. Oxford University Press, New York

Petersson M (2006) Myanmar in EU-ASEAN relations. Asia Eur J 4(4):563-581. https://doi.org/10.1007/ s10308-006-0085-z

Pevehouse J, Nordstrom T, Warnke K (2005) Intergovernmental organizations. In: The politics of global governance. Lynne Rienner, Boulder, pp 9-24 
Pickering S, Lambert C (2002) Deterrence: Australia's refugee policy. Curr Issu Crim Just 14(1):65-86. https://doi.org/10.1080/10345329.2002.12036247

Poe SC (1992) Human rights and economic aid allocation under Ronald Reagan and Jimmy Carter. Am J Polit Sci 36(1):147-167. https://doi.org/10.2307/2111428

Poe SC, Tate CN (1994) Repression of human rights to personal integrity in the 1980s: a global analysis. Am Polit Sci Rev 88(4):853-872

Poe SC, Neal Tate C, Keith LC (1999) Repression of the human right to personal integrity revisited: a global cross-national study covering the years 1976-1993. Int Stud Quart 43(2):291-313

Pogge T (2002) World poverty and human rights. Polity Press, Cambridge

Pogge T (2005) Severe poverty as a violation of negative duties. Ethics Int Affairs 19(1):55-83. https://doi. org/10.1111/j.1747-7093.2005.tb00490.x

Pollard VK (1970) ASA and ASEAN, 1961-1967: southeast Asian Regionalism. Asian Surv 10(3):244-255

Posner EA (2014) The twilight of human rights law. Oxford University Press, New York

Posner EA, Vermeule A (2004) Transitional justice as ordinary justice. Harv Law Rev 117(3):761-825

Rajagopal B (2006) Counter-hegemonic international law: rethinking human rights and development as a third world strategy. Third World Q 27(5):767-783. https://doi.org/10.1080/01436590600780078

Ramcharan BG (1989) The concept and present status of the international protection of human rights: forty years after the universal declaration. Martinus Nijhoff Publishers, Boston

Rawls J (1999) The law of peoples. Harvard University Press, Cambridge

Reif L (2004) The ombudsman, good governance and the international human rights system. Martinus Nijhoff Publishers, Leiden

Rejali D (2009) Torture and democracy. Princeton University Press, Princeton

Renshaw CS (2013) The ASEAN human rights declaration 2012. Hum Rights Law Rev 13(3):557-579. https ://doi.org/10.1093/hrlr/ngt016

Reus-Smit C (2001) Human rights and the social construction of sovereignty. Rev Int Stud 27:519-538. https ://doi.org/10.1017/s0260210501005198

Richards DL, Gelleny RD, Sacko DH (2001) Money with a mean streak? Foreign economic penetration and government respect for human rights in developing countries. Int Stud Quart 45(2):219-239. https:// doi.org/10.1111/0020-8833.00189

Risse T (1999) International norms and domestic change: arguing and communicative behavior in the human rights area. Polit Soc 27(4):529-559

Risse T, Ropp SC, Sikkink K (1999) The power of human rights: international norms and domestic change, Thomas R, Ropp SC, K Sikkink (eds). Cambridge University Press, New York

Robertson AH (1981) The implementation system: international measures. In: The international bill of rights: the covenant on civil and political rights, pp 332-369

Ruggie JG (1995) The false premise of realism. Int Secur 20(1):62-70

Rummel RJ (1963) Dimensions of conflict behavior within and between nations. Northwestern University, Evanston

Sandoval C (2013) The inter-American system of human rights and approach. In: Scott S, Nigel R (eds) Routledge handbook of international human rights law. Routledge, London, pp 427-443

Schmitz HP, Sikkink K (2002) International human rights. In: Carlsnaes W, Risse T, Simmons BA (eds) Handbook of international relations. Sage Publications, London, pp 517-537

Sen A (1999) Development as freedom. Anchor Books, New York

Shue H (1996) Basic rights: subsistence, affluence and US foreign policy. Princeton University Press, Princeton

Sidel JT (1995) The languages of legitimation. In: Alagappa M (ed) Political legitimacy in Southeast Asia: the quest for moral authority. Stanford University Press, Standford, pp 136-169

Simmons BA (2009) Mobilizing for human rights: international law in domestic politics. Cambridge University Press, New York

Smith H (2020) We left fearing for our lives': doctors set upon by mob in Lesbos. The Guardian. https:// www.theguardian.com/world/2020/mar/04/we-left-fearing-for-our-lives-doctors-set-upon-by-mob-inlesbos

Solingen E (1999) Asean, Quo Vadis? Domestic coalitions and regional co-operation. Contemp Southe Asia 21(1):30-53. https://doi.org/10.1355/cs21_1b

Stammers N (2009) Human rights and social movements. Pluto Press, London

Steiner HJ, Alston P (1996) International human rights in context: law, politics, morals: text and materials. Clarendon Press, Oxford

Talbott WJ (2005) Which rights should be universal?. Oxford University Press, Oxford

\section{SN Social Sciences}

A SPRINGER NATURE journal 
Tan H-L (2011) The ASEAN intergovernmental commission on human rights: institutionalising human rights in Southeast Asia. Cambridge University Press, Cambridge

Tasioulas J (2015) On the foundations of human rights. In: Rowan C, Matthew L, Massimo R (eds) Philosophical foundations of human rights. Oxford University Press, New York, pp 45-70

Tatsuo I (1999) Liberal democracy and Asian orientalism. In: Bauer JR, Bell DA (eds) The East Asian challenge for human rights. Cambridge University Press, Cambridge, pp 27-59

Taylor JG (1999) East Timor: the price of freedom. Zed Books, New York

Taylor M, Herman VM (1971) Party systems and government stability. Am Polit Sci Rev 65(1):28-37

Than TMM (2006) Myanmar: challenges galore but opposition failed to score author(S). Southe Asian Affairs 2006:183-207

The Human Rights Institute and the Leadership Conference on Civil and Human Rights (2012) The road to rights: establishing a domestic human rights institution in the United States. https://web.law.columbia. edu/sites/default/files/microsites/human-rights-institute/the_road_to_rights_post_conference_report.pdf

The New York Times (1977) Marcos denies U.S. report on rights violations. The New York Times, January 8. https://www.nytimes.com/1977/01/08/archives/marcos-denies-us-report-on-rights-violations.html

The World Bank (2018) GDP (Current US\$). https://data.worldbank.org/indicator/NY.GDP.MKTP.CD

The World Conference on Human Rights (1993) Vienna declaration and programme of action. Vienna Declaration and Programme of Action

Thio L (1999) Implementing human rights in ASEAN countries: 'promises to keep and miles to go before $\mathrm{i}$ sleep'. Yale Hum Rights Dev Law J 2(1):1-86

Transparency International (2018) Corruption perceptions index 2018. https://www.transparency.org/cpi2018

Tsutsui K, Wotipka CM (2004) Global civil society and the international human rights movement: citizen participation in human rights international nongovernmental organizations. Soc Forces 83(2):587620. https://doi.org/10.1353/sof.2005.0022

United Nations (2003) International covenant on civil and political rights CCPR/C/78/D/829/1998

United Nations Convention on the Rights of the Child (2007) General Comment No. 8 (2006), vol CRC/C/ $\mathrm{GC} / 8$

Universal Rights Group (n.d.) A rough guide to the regional human rights system. https://www.unive rsal-rights.org/human-rights-rough-guides/a-rough-guide-to-the-regional-human-rights-systems/. Accessed 31 July 2020

U.S Department of State (2019) Secretary of state Michael R. Pompeo remarks to the press. U.S Department of State. https://www.state.gov/secretary-of-state-michael-r-pompeo-remarks-to-the-press-3/

Volgy TJ, Fausett E, Grant KA, Rodgers S (2008) Identifying formal intergovernmental organizations. J Peace Res 45(6):837-850. https://doi.org/10.1177/0022343308096159

Wainwright E (2018) Human rights and the Trump administration. The United States Studies Centre at the University of Sydney, vol July. https://doi.org/10.1111/fcre.12342

Waltz KN (1979) Theory of international politics. Addison-Wesley Pub. Co., Reading

Waltz S (2002) Reclaiming and rebuilding the history of the universal declaration of human rights. Third World Q 23(3):437-448. https://doi.org/10.1080/01436590220138378

Wapner P (2002) Introductory essay: paradise lost? NGOs and global accountability. Chicago J Int Law 3(1): 155

Ward B (2018) Europe's climate of intolerance: political leaders across the region engage in hateful and divisive rhetoric. Human Rights Watch.https://www.hrw.org/news/2018/03/06/europes-climate-intolerance

Welch RM (2017) National Human Rights Institutions: domestic Implementation of International Human Rights Law. J Hum Rights 16(1):96-116. https://doi.org/10.1080/14754835.2015.1103166

Woods D (1992) Civil Society in Europe and Africa: limiting state power through a public sphere. Afr Stud Rev 35(2):77-100

Wotipka CM, Tsutsui K (2008) Global Human rights and state sovereignty: state ratification of international human rights treaties, 1965-2001. Sociol Forum 23(4):724-754

United Nations Department of Economic and Social Affairs (UNDESA) Disability (n.d.) History of United Nations and persons with disabilities - the first millennium decade. https://www.un.org/development/ desa/disabilities/about-us/history-of-united-nations-and-persons-with-disabilities-the-first-millennium -decade.html

Zagorin P (2003) How the idea of religious toleration came to the west. Princeton University Press, Princeton

Zakaria F, Lee KY (1994) culture is destiny: a conversation with Lee Kuan Yew. Foreign Affairs 73(2):109-126 